\title{
Articles
}

\section{Strategic Contractual Inefficiency and the Optimal Choice of Legal Rules}

\author{
Ian Ayres† and Robert Gertner $+\dagger$
}

Two separate groups of academics have brought about a renaissance of sorts in the analysis of incomplete contracts. Law and economics scholars-writing in law reviews-have shown renewed interest in how efficiencyminded lawmakers should fill gaps in incomplete contracts. ${ }^{1}$ Yet even before this, a group of economists - writing in economics journals-began developing new theories of "incomplete contracting" that are still largely unincorporated in the legal literature. ${ }^{2}$ These two strands of analysis have remained largely

$\dagger$ Visiting Professor, Yale Law School (Fall 1991); Professor, Stanford Law School.

i† Associate Professor, University of Chicago, Graduate School of Business. Randy Barnett, Richard Craswell, Richard Epstein, Stan Henderson, Jason Johnston, Jody Kraus, Eric Rasmusen, Alan Schwartz, Bob Scott, and Peter Siegelman provided helpful comments.

1. Lucian A. Bebchuk \& Steven Shavell, Information and the Scope of Liability for Breach of Contract, 7 J.L. ECON. \& ORGanZation 284 (1991); Jules L. Coleman et al., A Bargaining Theory Approach to Default Provisions and Disclosure Rules in Contract Law, 12 HARV. J.L. \& PUB. POL'Y 639 (1989); Richand Craswell, Contract Law. Default Rules, and the Philosophy of Promising, 88 MicH. L. REV. 489 (1989); Jason S. Johnston, Strategic Bargaining and the Economic Theory of Contract Default Rules, 100 YALE L.J. 615 (1990); Alan Schwartz, A Theory of Loan Priorities, 18 J. LEGAL STUD. 209 (1989); Robert E. Scott, A Relational Theory of Default Rules for Commercial Contracts, 19 J. LEGAL STUD. 597 (1990); Ian Ayres \& Robert Gertner, Filling Gaps in Incomplete Contracts: An Economic Theory of Default Rules, 99 YALE L.J. 87 (1989); see also Charles J. Goetz \& Robert E. Scott, The Limits of Expanded Choice: An Analysis of the Interactions Between Express and Implied Contract Terms, 73 CAL. L. REV. 261 (1985).

2. See, e.g., OLIVER WILlIAMSON, THE ECONOMIC INSTITUTIONS OF CAPITALISM (1985); Oliver D. Hart \& Bengt Holmstrom, The Theory of Contracts, in ADVANCES IN ECONOMIC THEORY-FIFTH WORLD CONGREss 71 (Truman F. Bewley ed., 1987); Sanford J. Grossman \& Oliver D. Hart, The Costs and Benefits of Ownership: A Theory of Vertical and Lateral Integration, 94 J. POL. ECON. 691 (1986); Milton Harris \& Bengt Holmstrom, On the Duration of Agreements, 28 INT'L ECON. REV. 389 (1987); Robert M. 
independent, in part because they focus on two different forms of contractual incompleteness.

Legal scholars use the term "incomplete contracting" to refer to contracts in which the obligations are not fully specified. A contract to sell a good would be "obligationally" incomplete, for example, if it failed to specify the price, quantity, or date of delivery. In contrast, a contract is obligationally complete if the obligations of the parties are fully specified for all future states of the world. A contract that failed to specify the seller's obligations in the event of a flood or the buyer's breach would thus be obligationally incomplete. Default rules respond to obligational incompleteness by filling these obligational gaps. ${ }^{3}$

Economics scholars, on the other hand, use the term "incomplete contracting" to refer to contracts that fail to fully realize the potential gains from trade in all states of the world. These contracts are considered "contingently" incomplete or "insufficiently state contingent." For example, a contract to deliver certain goods to a house tomorrow for $\$ 100$ may be obligationally complete in the sense that obligations are fully specified for all future states of the world. However, the contract may be insufficiently state contingent in that the contractual obligations fail to fully realize the potential gains from trade in all states of the world. ${ }^{4}$ Contracts that are "insufficiently state contingent" (contingently incomplete) give private parties incentives-in at least some states of the world-to either renegotiate or breach the original contract to realize these additional gains from trade. ${ }^{5}$

Townsend, Optimal Contracts and Competitive Markets with Costly State Verification, 21 J. ECON. THEORY 265 (1979); David M. Kreps, Static Choice in the Presence of Unforeseen Contingencies (Aug. 1988) (unpublished manuscript, on file with authors); Kathryn E. Spier, Incomplete Contracts in a Model with Adverse Selection and Exogenous Costs of Enforcement (Dec. 1988) (unpublished manuscript, on file with authors).

The work by economists is especially noteworthy because it represents one of the few times that economics theorists of the first order have taken the lead in analyzing a core legal issue. Indeed, economics departments are taking an interest in contracts at a time when the legal academy has shown, if anything, waning interest. Several leading law schools, for example, have no scholars actively writing in the area. And while law schools feel a need to have active scholars in such fields as international law and tax, it is an indicia of the academy's complacency that a deficiency in contract scholarship is not identified as an appointments concern.

3. Determining whether a contract has a gap, that is, whether it is obligationally incomplete, raises important issues of contractual interpretation. By establishing the necessary and sufficient conditions for contracting around a default rule, contract law simultaneously defines when contracts have obligational gaps. See Ayres \& Gertner, supra note 1, at 119-21. Contract law can at times respond to obligational incompleteness by rescinding all obligations. For example, the rescission default is common for contracts that are found void for vagueness. $l d$.

4. It is also possible that contractual obligations may be contingent on too many conditions or incorrect events to realize all the potential gains from trade. If the parties fail to contract around a default rule that makes their obligations contingent on various events that are irrelevant to the gains of trade from the exchange, the contract would be incomplete because it would be contingent on the wrong contingencies. For example, an optimal auto insurance contract should be insensitive to certain risk factors, such as the insured's previous accident history, yet competitive insurance contracts are often dependent on these factors.

5. This statement is the obverse of Shavell's insight that contract parties lack incentives to breach or renegotiate complete contingent contracts. Steven Shavell, Damage Measures for Breach of Contract, 11 BELL J. ECON. 466 (1980). 
Setting damages for breach of contract can cause courts to respond to both types of contractual incompleteness-obligational and contingency. Since a contractual promise is a promise "to perform or to pay damages," contracts that do not set the amount of breach damages for each party fail to fully specify the parties' obligations under all future states of the world; hence, these contracts are "obligationally incomplete." Most contracts are obligationally incomplete in this sense, because most contracts do not have liquidated damages clauses. Courts, in determining the amount of damages for breach of contract, are often called upon to fill this obligational gap.

This form of gap filling, however, has at times been used to respond to contracts that are "insufficiently state contingent." For example, imagine a contract which, because of an unanticipated state of the world, cannot be carried out or can only be carried out with great losses. This contract is obligationally incomplete, since it does not specify the damages for breach in the unanticipated state of the world, and it is contingently incomplete because it does not make the parties' contractual duties dependent upon the unanticipated state of the world. When faced with such contracts, courts use the excuse doctrines of impossibility ${ }^{7}$ and impracticability ${ }^{8}$ to fill the damages gap with zero damages.

By filling obligational gaps with provisions that are state contingent, courts can respond to both types of contractual incompleteness. Awarding zero damages when there is excused performance is one way to use obligational incompleteness regarding damages to correct the flaws of contingently incomplete contracts. ${ }^{9}$ As such, the judicious use of obligational gap filling can reduce the cost of writing contracts that are contingently incomplete.

Filling the damages gap with state contingent damage measures, however, does not collapse the difference between obligational and contingency incompleteness. Contracts with liquidated damages clauses may be obligationally complete (because obligations are fully specified in all states of the world) ${ }^{10}$

6. Globe Refining Co. v. Landa Cotton Oil Co., 190 U.S. 540,543 (1903) (Holmes, J.); Oliver W. Holmes, The Path of the Law, 10 HARV. L. REV. 457, 462 (1897).

7. RESTATEMENT (SECOND) OF CONTRACTS § 261(d) (1981).

8. Id. \& 261(a).

9. These excuse doctrines make the default damage rule more dependent on the states of the world when the contract is insufficiently state contingent.

10. Thus, while it is common in the contractual literature to suggest that contracts are necessarily incomplete, this statement is only true with regard to contingency completeness. Even a long term contract can be made obligationally complete with fairly few words. For example, suppose Seller promises to provide 100 gallons of $10 \mathrm{~W} 40$ oil to [specific address] before noon on the first day of each month for the next 10 years. Buyer agrees to pay Seller $\$ 1000$ in cash at the time of delivery. If Buyer or Seller breaches this contract for any month, the breaching party will owe the nonbreaching party $\$ 1000$, and all other contractual obligations will be rescinded.

This contract is massively incomplete in the contingency sense (because, for example, the oil price is not dependent on the state of the world), but is obligationally complete.

Some would argue, however, that no contract could be obligationally complete (inciuding the foregoing one), because no obligational words are unambiguous: "Most fundamentally, no text can completely specify its own means of interpretation. A contractual statement that purported to be such a complete specification would itself have to be interpreted by some set of rules of interpretation." David Charny, Hypothetical Bargains: The Normative Structure of Contract Interpretation, 89 MICH. L. REV. 1815, 1819 (1991). 
but not contingently complete (because obligations do not exploit gains from trade in all states of the world). Moreover, making default damage obligations more state contingent may not fully exploit all gains from trade. ${ }^{11}$ Thus, courts may be unable to respond efficiently to contingency incompleteness by filling obligational gaps - because the contract may not have any obligational gaps or may not have the right gaps to allow a court to efficiently reallocate the parties' obligations. Efficient contract law needs to be responsive to both forms of incompleteness. ${ }^{12}$ This Article shows how the choice of obligational default rules affects the strategic reluctance of parties to enter into sufficiently state contingent contracts and thereby maximize gains from trade.

We examine how transaction costs and market power affect the strategic incentives to contract around different default rules. In a recent article, we argued that strategic bargaining could impede parties from contracting around inefficient default rules. ${ }^{13}$ Last year, Jason Johnston went beyond our arguments to show how the incidence of market power could impact the inefficiency of strategic bargaining. Johnston's article could be read to imply that even in a world without transaction costs, the choice of contractual defaults could impact the types of contracts made and the social benefits of contracting. ${ }^{14}$

In contrast to the implications of Johnston's article, we explicitly propose that default rules do not affect the contractual equilibrium when it is costless to contract and when both parties know the default rule. This is what we characterize as our "irrelevance conjecture"-the choice of default becomes irrelevant when it is costless to contract and when the default rule is common knowledge. ${ }^{15}$ Without these transaction costs (and when the default rule is common knowledge), strategic bargaining can still cause inefficient contracting, but the same contractual equilibrium will be reached by private parties, regardless of the default rule.

When even slight costs in contracting around a default rule are introduced, however, the choice of default rule can affect both the contractual equilibrium and the net social benefits of contracting, i.e., efficiency. Whereas costless contracting produces a relatively simple contractual equilibrium (which is independent of the default rule), the introduction of transaction costs produces

11. Maximizing gains from trade in some states of the world may require changing more than the default damages amount. For example, in addition to imposing positive damages, it may be efficient to require the seller to sell a reduced amount or to require the buyer to accept slightly nonconforming goods at a lower price.

12. Neither form of contractual inefficiency implies contractual failure. Parties may leave obligational gaps in contracts because the gap-filling default rule maximizes gains from trade. Further, parties may write contingently incomplete contracts because the expected costs of renegotiation or court settlement (for unlikely future events) may be cheaper than the certain ex ante costs of drafting a contingently complete contract.

13. Ayres \& Gertner, supra note 1 , at 94.

14. See Johnston, supra note 1 , at 617-20; discussion infra Part I.B.

15. For a definition of common knowledge and the importance of this assumption, see infra text accompanying notes 93-94. 
a proliferation of equilibrium contracts that depend on both the choice of default rule and a variety of underlying structural variables.

In fact, the introduction of transaction costs can actually exacerbate the inefficiencies of strategic bargaining-so the gains from contracting can fall by more than the size of the transaction costs. We show that the inefficiencies of strategic bargaining, therefore, are not necessarily limited by the size of transaction costs. The choice of an inefficient default rule can generate inefficiencies that, because of strategic bargaining, are much greater than the cost of contracting around the inefficiency.

In short, the introduction of even slight transaction costs will make the determination of efficient legal rules dramatically more difficult. We demonstrate that the behavior of contracting parties can change significantly in response to extremely small changes in other, more subtle underlying variables-such as the valuations of particular buyers.

A main thesis of this Article is that relatively simple contractual settings can give rise to enormous complexity. While we can show that different default rules-and in certain circumstances, immutable rules-would be theoretically efficient, our model suggests that there is small hope that lawmakers will be able to divine the efficient rule in practice.

These results strengthen the growing consensus among contract scholars that default rules should not simply be the hypothetical contract that parties would choose in a world without transaction costs. ${ }^{16}$ The hypothetical contract standard fails to account for the inefficiencies that can be caused by strategic bargaining under conditions of asymmetric information and how these inefficiencies depend upon, and can be exacerbated by, the costs of contracting around a given default rule. When the parties have symmetric information, the hypothetical contract standard yields efficient results. When the parties have asymmetric information, however, the hypothetical contract standard fails to provide an effective framework for choosing efficient rules.

This Article uses some of the new modeling techniques that economists have been using to model contingency incompleteness to analyze legal responses to obligational incompleteness. ${ }^{17}$ Methodologically, the law and economics

16. Advocates of the hypothetical contract approach include Frank H. Easterbrook \& Daniel R. Fischel, The Corporate Contract, 89 ColuM. L. REv. 1416 (1989). For a fuller discussion, see Ayres \& Gertner, supra note 1 , at $89-90$. Jules Coleman has independently suggested that law and economics analysis should move away from the "hypothetical contract" terminology to a more direct consideration of which default rules promote efficiency: "[T]here appears to be nothing expressed by the concept of hypothetical consent that is not already captured in the idea of rational self-interest." JULES COLEMAN, RISKS AND WRONGS 272 (forthcoming 1992) (on file with author).

David Charny provides an important examination of hypothetical contracts in a recent article. Charny, supra note 10 . His analysis provides several more examples of when hypothetical contracting is not the preferred method of choosing contractual default rules. Moreover, Charny shows that the judicial choice of hypothetical provisions has been at times "incorrect, [and] perhaps even incoherent." Id. at 1815.

17. With respect to contingency incompleteness, the legal academy is likely to profit from the work of the economics academy. With rare (but celebrated) exceptions, courts have been unwilling to set aside or reformulate contracts that are insufficiently state contingent. See, e.g., Aluminum Co. of Am. v. Essex 
of default rules has entered a "second generation" of analysis that begins by explicitly recognizing private preference for different types of contracts. ${ }^{18}$ Typically, these models assume either two types of buyers or two types of sellers. The two types are defined so that different contractual provisions will maximize the gains of trade between the buyers and sellers. Though the assumption that two types of buyers deal with one type of seller seems crude, it represents an important advance over earlier economic analysis of contractual gap filling. ${ }^{19}$ The "first generation" analysis often discovered the single contractual rule that would maximize the gains from trade for all contracting parties. In an important sense, however, this mode of analysis proved too much: if a rule enhances efficiency for all contracting types, then one should be agnostic about whether to make the rule mandatory or merely a default around which parties can contract.

The decision to use default rules, however, grows out of a realization that contracting parties will often prefer different contractual provisions-and that contractual flexibility can therefore increase the total gains from trade. To analyze the choice of default rules in a context where contractual flexibility is important, contracting models need to allow the possibility that some parties might want different contracts. By allowing for two different types of contracts, these "second generation" models are better suited to analyze whether a particular default rule maximizes the total gains from trade-because these models can assess whether parties are likely to contract for the different obligations and at what cost.

Though our model of default rules is part of this "second generation" analysis, it retains the traditional factual scenario used to study default rules-the case of Hadley v. Baxendale. ${ }^{20}$ Hadley continues to be one of the

Group, Inc., 499 F. Supp. 53 (W.D. Pa. 1980). This reluctance to remake or rescind an express transaction may grow out of a strong empirical belief that the court is institutionally inept to make this sort of ex post determination. Scott, supra note 1 , at 615 . Yet as a theoretical matter, the scope of potential reforms goes far beyond the current all-or-nothing judicial proclivities. Courts might save both ex ante negotiation costs and ex post renegotiation costs by reformulating contractual obligations that turn out to be insufficiently state contingent. From a social welfare perspective, there will be a horse race between the costs of renegotiating contracts that are ex post inefficient and the costs of empowering courts to make ex post adjustments. Of course, as an empirical matter we may conclude that courts institutionally will almost always lose this race. Yet even here, future analysis of both renegotiation and reformation may suggest situations where the contest is closer.

18. For examples of this form of modeling, see Johnston, supra note 1, at 626-39; Schwartz, supra note 1 . The assumption of two types of players in games of asymmetric information has become standard in economics in the last decade, with dozens of papers employing this modeling technique. See also Ian Ayres, Playing Games With the Law, 42 STAN. L. REV. 1291 (1990) (reviewing ERIC RASMUSEN, GAMES AND INFORMATION (1989)).

19. See Ian Ayres, The Possibility of Inefficient Corporate Contracts, 60 U. CIN. L. REV. (forthcoming Fall 1991).

20. 156 Eng. Rep. 145 (1854). In Hadley, a miller in Gloucester contracted with a carrier to have a broken crank shaft transported to Greenwich. The shipment was delayed, and the miller sued the carrier for consequential damages of the profits lost while the mill was inoperative. The court, holding that only foreseeable consequential damages should be awarded, reversed a damage award and remanded for a new trial. Id. 
most analyzed contract cases in law and economics literature. ${ }^{21}$ Though Hadley provides our starting point, we show that our analysis has relevance to a wide range of contractual defaults. 22

In Part I, we extend the recent insights of Johnston to show that the inefficiencies of strategic bargaining depend on the incidence of market power and that these inefficiencies can persist even when it is costless to contract around a given default. A central result is that the choice of a default rule will not affect how people contract when it is costless to contract for alternative obligations and when both parties are aware of the prevailing default.

In Parts II and III, we relax both of these prerequisites to examine how the contractual equilibrium can be affected either by the presence of transaction costs or by uncertain or mistaken beliefs about the prevailing default rule. In particular, we show that the presence of even slight transaction costs can dramatically change both the types of contracts that people write and the net gains from trade. Finally, in Part IV, we explore the sources of and relation between contractual failure and contractual incompleteness with an eye towards structuring efficient default and immutable rules.

\section{Costless Contracting ARound KNown Defaults}

\section{A. Johnston's Insight into the Importance of Market Power}

Our original model of Hadley $v$. Baxendale suggested that denying consequential damages might promote efficiency by giving high-value shippers an incentive to contract around the damage limitation and thus allow the carrier to take more efficient precautions..$^{23}$ We argued that the limitation on consequential damages was a "penalty" or "information-forcing" default rule, ${ }^{24}$ which serves as a counterexample to those who would argue that default rules should simply replicate the contracts that a majority of parties would make in

21. See Ayres \& Gertner, supra note 1; Bebchuk \& Shavell, supra note 1; William Bishop, The Contract-Tort Boundary and the Economics of Insurance, 12 J. LEGAL STUD. 241, 254 (1983); Richard A. Epstein, Beyond Foreseeability: Consequential Damages in the Law of Contract, 18 J. LEGAL STUD. 105 (1989); Johnston, supra note 1; Melvin A. Eisenberg, The Principle of Hadley v. Baxendale (Apr. 30, 1991) (unpublished manuscript, on file with authors).

22. See infra text accompanying notes 104-10.

23. See Ayres \& Gertner, supra note 1 , at 103-04.

24. The term "penalty" was introduced in our article. See id. at 91. Jack Coffee, however, introduced the more teleological term "information revealing." John C. Coffee, Jr., The Mandatory/Enabling Balance in Corporate Law: An Essay on the Judicial Role, 89 CoLUM. L. REV. 1618, 1623 (1989). Bob Scott has similarly coined the term "information forcing" to describe the effect of a penalty default. Scott, supra note 1, at 609. The information-forcing effect of Hadley had been noticed by a number of authors. See, e.g., RICHARD A. POSNER, ECONOMIC ANALYSIS OF LAW 114 (3d ed. 1986); Randy E. Barneth, The Sound of Silence: Default Rules and Contractual Consent, 78 VA. L. REV. (forthcoming May 1992); Bishop, supra note 21, at 255; Frank H. Easterbrook \& Daniel R. Fischel, Limited Liability and the Corporation, $52 \mathrm{U}$. CHI. L. REV. 89, 113 n.45 (1985); Charles J. Goetz \& Robert E. Scott, Enforcing Promises: An Examination of the Basis of Contract, 89 YALE L.J. 1261, 1299-1300 (1980); Robert E. Scoth, The Case for Market Damages: Revisiting the Lost Profits Puzzle, 57 U. CHI. L. REv. 1155, 1196 (1990). 
the absence of transaction costs. ${ }^{25}$ Johnston's article went beyond our analysis by exploring a new form of strategic inefficiency: if the carrier has market power, then information-forcing defaults may not be sufficient to induce highvalue shippers to reveal their private information. ${ }^{26}$ Johnston convincingly demonstrated that a shipper's incentive to reveal information depends upon the incidence of market power. In our original model, competition drove carriers to price at zero profits. Johnston's model shifted the market power to the carriers-so that carriers attempted to infer the shippers' valuation in order to price discriminate between the two types of shippers and to extract a larger portion of the gains from trade. In this situation, high-value shippers may not want to contract around a rule which limits consequential damages because doing so might make it easier for the carrier to exploit its market power against them.

A high-value shipper asking for additional damages would not only give the carrier information necessary to take more efficient precautions, but it would also let the carrier raise the price to reflect the shipper's higher valuation. In this situation, the carrier would charge a supracompetitive price for additional insurance and might thereby cause high-value shippers to strategically choose not to bargain around the inefficient foreseeability default.

It is important to note that Johnston derives this result in a model in which parties can costlessly contract around any default. ${ }^{27}$ His article might be read to suggest that even in a world with costless contracting, choosing the "wrong"

25. Ayres \& Gertner, supra note 1 , at 91 .

26. Johnston's article extended our analysis by explicitly considering the effects of giving the carrier, and not the shipper, the power to make take-it-or-leave-it offers. Johnston, supra note 1, at $625-26,628$. When the carrier has market power, Johnston explains, high-value shippers may have strategic incentives not to contract around the "information-forcing" default of limited liability:

[A high-value shipper] has no incentive to reveal her value when the default provides only limited liability, because if the revelation is credible and fully informs the carrier as to the shipper's value, the carrier will extract all of this value by making a take-it-or-leave-it offer of full coverage at a price precisely equal to carrier value.

Id. at 629 (footnote omitted). In our original model (assuming that shippers had market power), we showed that high-value shippers may fail to bargain around an inefficient default rule (regardless of whether such contracting would be costless), because failure to contract might allow them to receive a price that would be effectively subsidized by the presence of low-value shippers. Ayres \& Gertner, supra note 1, at 110-11. Thus, we showed that a contractual party with private information that could increase the gains from exchange if revealed might have strategic incentives to conceal that information by failing to contract around a default that allowed consequential damages.

27. Johnston referred to this zero-transaction cost perspective as the "Coasean Contractual Theory." Johnston, supra note 1, at 623 . The phrase, of course, refers to the recent Nobel Prize winner Ronald Coase and the famous Coase Theorem. See Ronald Coase, The Problem of Social Cost, 3 J.L. \& EcoN. 1 (1960). Coase, however, has bristled at the use of the term "Coasean" to describe worlds without transaction costs, because he views such worlds as nonexistent and therefore less interesting. See Robert Ellickson, The Case for Coase and Against Coaseanism, 99 YALE L.J. 611, 612-13 (1989).

Johnston argues that the choice of default rule will influence contractual efficiency even though he "assume[s] that the only obstacle to transacting around the default is the potential strategic loss in revealing private information." Johnston, supra note 1 , at 627 . Our original model demonstrated that the choice of default rule could affect contractual efficiency, but our model relied on transaction costs to eliminate the incentive for low-value shippers to contract around a default that allowed consequential damages. Ayres \& Gertner, supra note 1, at 110-11. 
default could exacerbate strategic contractual behavior and generate additional inefficiencies. In short, Johnston's extended analysis of alternative default rules suggests that even when contracting is costless, default choice matters. ${ }^{28}$

\section{B. The Irrelevance of Default Choice When Parties Can Costlessly Contract Around Known Defaults}

Johnston correctly notes that the contractual equilibrium depends on the incidence of market power and that inefficient contracting can persist even when it is costless to contract around the prevailing default rule. However, the implication in his article that the inefficiency will depend on the type of the default cannot be sustained. When it is costless to contract around a default that is known by both parties, the existence of the default rule will not affect the contractual equilibrium. Though there still may be contractual inefficiencies because of strategic incentives to withhold information, changing the default rule will not change the contractual equilibrium.

This insight supports our irrelevance conjecture-when it is costless to contract around known defaults, the choice of the default rule is irrelevant. We refer to this proposition as an irrelevance "conjecture" because we have not provided a formal proof. ${ }^{29}$ Our intuition for the irrelevance conjecture is that if each party can costlessly offer an alternative to the default obligation, then the equilibrium sequence of offers and counteroffers-regardless of the bargaining game-should be unaffected by the choice of the default. Imagine, for example, a world where contracting is costless, and courts only enforce contracts that explicitly address whether consequential damages would be awarded for breach. All valid offers would then (costlessly) contain a provision addressing this issue. However, if contract law instead provided a default rule regarding consequential damages, there is no reason why any of the offers, counteroffers, or eventual contracts would change. The offers of individual parties would costlessly substitute the same provisions whenever the default rule was different. Of course, asymmetric information could still cause contractual inefficiencies, but when contracting around a default rule is costless, those inefficiencies will be the same regardless of the initial gap filler. In sum, because every possible contractual outcome has the same payoff to each party

28. Thus, while maintaining an assumption of costless contracting, Johnston argues that a foreseeable damage default might be less efficient than consequential damages would be: "[A]n assumption which I shall maintain throughout the analysis, except where it is explicitly relaxed ... [is] that the only obstacle to transacting around the default is the potential strategic loss in revealing private information, and therefore that conventional or direct transaction costs are minimal." Johnston, supra note 1, at 627 .

29. Some might argue that the Coase Theorem, see Coase, supra note 27 , provides an a fortiori demonstration of the result. Our concept of default irrelevance, however, applies whenever it is costless for parties to offer and accept a contract that alters a default rule, while the Coase Theorem requires that all transactions be costless. Thus, we conjecture that the default choice should be irrelevant even when there is a fixed cost for each offer as long as the fixed cost of offering a nondefault contract is the same as offering a default contract. 
independent of the default rule, the default rule should not affect the equilibrium. . $^{30}$

The irrelevance of default choice when contracting is costless can be shown by formalizing Johnston's own insight that shifting the incidence of market power can exacerbate the strategic contractual inefficiencies. Assume that a carrier with market power is dealing with two types of shippers who value the carrier's performance differently. Suppose, for example, that one shipper would gain $\$ 100\left(v_{l}\right)$ from performance and that the other shipper would gain $\$ 150$ $\left(v_{h}\right)$ from performance. There is sufficient asymmetric information such that the carrier does not know the type of any particular shipper, but does know that there is a $50 \%$ chance that a shipper has the higher valuation. ${ }^{31}$ Knowledge of how a particular shipper values performance is socially useful because the carrier can choose the appropriate level of precaution to insure that performance occurs. If a given shipper has a high valuation, it is efficient to take more precaution. But as Johnston suggested, high-value shippers may be reluctant to reveal this information, because it may allow the carrier to extract a larger portion of those shippers' $\$ 150$ value.

In the Appendix, we formally solve this model for contexts in which it is costless to contract around a given default. ${ }^{32}$ In this model, an obligationally complete contract specifies the price for carriage and the damages in the instance of carrier breach. To exercise its market power (and maximize profits), the carrier has incentives to offer a menu of alternative contracts to separate the low-value shippers from the high-value shippers. We show that for particular assumptions about the carrier's cost, the carrier will offer all shippers a menu with two contractual alternatives:

\section{(Alternative 1) Price to Ship $=\$ 137.50$, Damages for Breach $=\$ 150$ (Alternative 2) Price to Ship $=\$ 65.50$, Damages for Breach $=\$ 50$}

When confronted with this menu, high-value shippers will accept the first alternative, while low-value shippers will accept the second alternative.

30. This "irrelevance" theorem depends on some informational assumptions. First, for the default rule to be irrelevant, both parties must know which default rule is in effect. Second, it might be true that the choice of a default rule might affect a party's beliefs about which provision will be a focal point-thus coordinating the parties' choice among different possible equilibria. Finally, it may be possible that the choice of different defaults would affect the order of play-and hence the outcome of the bargaining game. We are indebted to Eric Rasmusen and Alan Schwartz for these points.

31. If the carrier is uncertain about the proportion of high- and low-value shippers, the analysis becomes more difficult. As long as a risk-neutral carrier has what Bayesian statisticians would call "prior beliefs" about this proportion, the carrier's profit-maximizing behavior will be based upon the expected proportion. Although in common parlance we might speak about carriers who "have no idea" about the proportion of high-value shippers, it is difficult to model tractably how such carriers would maximize profits. The implications of uncertainty about valuation distributions in an asymmetric information model are discussed in Steven Shavell, Strict Liability Versus Negligence, 9 J. LEGAL STUD. 1 (1980).

32. See infra Appendix. 
When it is costless to contract around default rules, the carrier can use a menu of offers to separate the two types of shippers. ${ }^{33}$ The menu is effective in forcing the shippers to reveal information, but there is a loss in efficiency. The only way the carrier can dissuade the high-value shipper from accepting the second alternative is by reducing the damages for breach to half of the lowvalue shipper's $\$ 100$ valuation. These undercompensatory damages for lowvalue shippers lead the carrier to inefficiently underinvest in precaution. ${ }^{34}$

The process of separation is graphically depicted in Figure $1 .^{35}$ The axes of the figure represent the two contractual terms at issue: the contract price and the contract damages. Thus, any point on the graph represents a potential contract. The figure plots three indifference curves comparing different sets of contracts. An indifference curve represents a set of contracts that gives a particular shipper equivalent returns from contracting (consumer surplus). A consumer should be indifferent about choosing among any of the points along an indifference curve. The curve labeled " 0 -surplus, high type" represents the set of contracts that would give a high-value shipper no returns from contracting. ${ }^{36}$ Consumers are not, however, indifferent about choosing among points off the indifference curve. Consumers receive more utility by accepting contracts located further toward the upper left-hand corner of the figure. Thus, the indifference curve labeled "positive surplus, high type" represents contracts where the high type would receive a constant positive surplus. ${ }^{37}$

33. This is a "screening" game in which the uninformed player (the carrier) moves first by offering a menu of contracts to distinguish among players with private information. See ERIC RASMUSEN, GAMES AND INFORMATION 133-36 (1989).

34. With asymmetric information, a carrier serving 500 shippers of each type with this menu of offers would generate gains from exchange of $\$ 37,500$. Without asymmetric information, however, the carrier would not have to engage in this socially inefficient process of price discrimination. Knowing the shipper's valuation, the carrier would take the efficient amount of precaution for all shippers (and extract all consumer surplus). With symmetric information, the expected gains from exchange would increase to $\$ 40,625$.

35. This analysis parallels the seminal modeling of Michael Rothschild \& Joseph Stiglitz, Equilibrium in Competitive Insurance Markets: An Essay on the Economics of Imperfect Information, 90 Q.J. ECON. 629 (1976); see also Phillippe Aghion \& Benjamin Hermalin, Legal Restrictions on Private Contracts Can Increase Efficiency, 6 J.L. ECON. \& ORGANIZATION 381 (1990); Ayres, supra note 19.

36. Intuitively, these indifference curves must be upward sloping because shippers would only be indifferent to paying a higher price if they could receive higher damages in the instance of breach.

37. This indifference curve is everywhere above and to the left of the high-value shippers' zero-surplus indifference curve. 
FIGURE 1. Indifference Curves for High-and Low-Damage Shipper Types:

Carrier Induces Separating Equilibrium with a Menu of Contract Offers

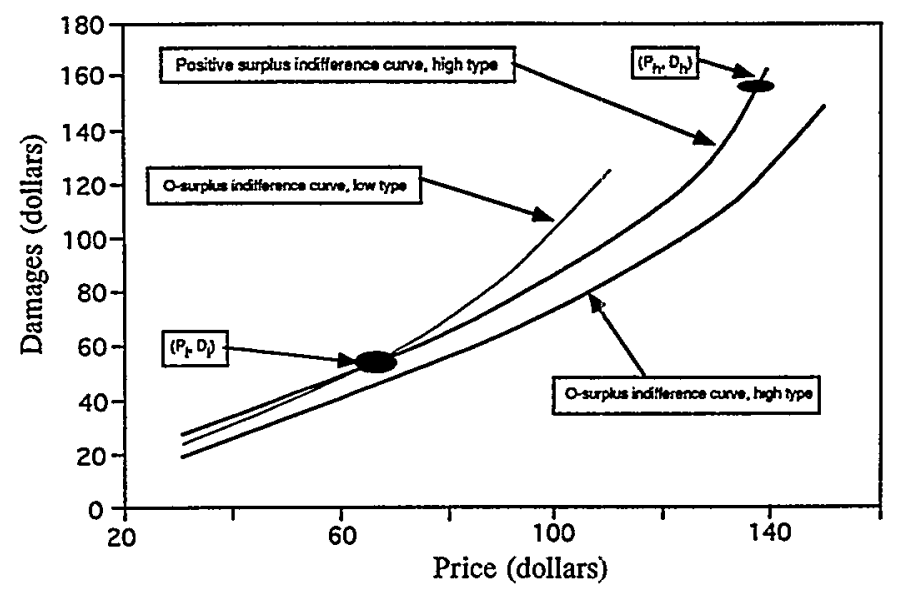

The carrier would like to perfectly price discriminate by extracting all the consumer surplus from each type of consumer. The carrier would accomplish this by offering each consumer a contract that was only infinitesimally better than no contract at all, i.e., a contract that was on (or infinitesimally above) the consumer's zero surplus indifference curve. ${ }^{38}$ The graph shows, however, that perfect exploitation is not possible when the carrier cannot distinguish highand low-value shippers. If the carrier offered a menu of contracts that attempted to drive both high- and low-value shippers to zero surplus, all high-value shippers would choose to accept the low-value offer. This can be seen in the graph by noting that the zero surplus indifference curve for the low-value shipper is everywhere above the zero surplus indifference curve for the highvalue shipper-and therefore yields high returns.

In order to induce high-value shippers to reveal their true identity, the carrier exploits the fact that high-value shippers are hurt more by contractual breach than low-value shippers (for the simple reason that they lose a higher value). This causes the low-value shippers to have steeper indifference curves. $^{39}$ The carrier can induce separation by offering a menu of two contracts that contains both a "carrot" and a "stick" for high-value shippers. The "carrot" for the high-value shipper is the carrier's commitment not to fully

38. Perfect price discrimination would entail choosing the efficient level of damages to maximize the consumer surplus that the carrier could extract from shippers. In the foregoing example, the carrier who could identify the shippers' valuations would offer low-value shippers a contract $(P=100, D=100)$ and would offer high-value shippers a contract $(P=150, D=150)$.

39. The high-value shipper is willing to pay a higher price in order to achieve a given level of damages. Thus, consider $P_{b}, D_{t}$ - a point where indifference curves for high- and low-value shippers intersect and look at how much more the two types of shippers would be willing to pay in order to receive a contract that had higher damages of 60 . We see that the steeper indifference curve for low-value shippers implies that highvalue shippers would be willing to pay more to receive this higher amount of damages (and still be indifferent). 
exploit information about the shipper's valuation. As outlined above, the first menu alternative offers a price of $\$ 137.50$ even though the carrier knows that in equilibrium the accepting shipper values the service at $\$ 150$. The "stick" for the high-value shipper is that the second alternative offers damages that are inefficiently low even for the low-value shipper. Because the high-value shipper has even more to lose from breach, the commitment to inefficient low damages deters the high-value shipper from wanting to accept the low price offer.

Figure 1 shows that the menu of offers $\left(P_{h}, D_{h}\right)$ and $\left(P_{l}, D_{l}\right)$ generates a separating equilibrium in which the carrier extracts all of the consumer surplus from the low type but only part of the consumer surplus from the high type. The "carrot" of only partial exploitation $\left(P_{h}<v_{h}\right)$ combined with the "stick" of inefficiently low damages $\left(D_{l}<v_{l}\right)$ overcomes the strategic reluctance of high-value shippers to reveal their type. The high-value shippers earn informational rents on the private knowledge of their information. Their asymmetric information works as a counterweight to the carrier's market power, allowing high-value shippers to split the gains from trade. As emphasized before, however, the process of separation reduces social welfare, because the stick of inefficient low damages means that in equilibrium carriers will not take efficient precaution for the contracts signed by low-value shippers. Costlessly offering. a menu of contracts does not therefore eliminate the strategic inefficiencies.

This example formalizes Johnston's point that strategic inefficiencies can persist even when it is costless to contract around a given default. ${ }^{40}$ The possibility that contractual inefficiencies will persist even when contracting is costless stands against a standard argument that without transaction costs, parties will contract for efficient terms. The persistence of inefficiencies depends, however, on our assumption that the parties cannot make the contract price (when there is no breach) contingent on the later determination of the shipper's type. This assumption of "nonverifiability" or "noncontractibility" is standard in the asymmetric information literature ${ }^{41}$ — but represents a restriction on the set of contracts that the parties can make. ${ }^{42}$

40. The insight that contractual inefficiencies may persist when contracting is costless has been captured in earlier economic models. See Aghion \& Hermalin, supra note 35; Rothschild \& Stiglitz, supra note 35.

41. For example, Shavell, supra note 5, at $472-73$, assumes that parties cannot contract on the random variables that determine the cost of performance or on reliance investment. Yet the damage rules he analyzes include reliance damages and expectation damages, both of which rely on ex post verifiability of these noncontractible parameters. Id. at 471 ; see also Johnston, supra note 1, at $650-52$.

42. Our assumption that it is impossible to write a contract contingent on shipper's type is also in tension with our assumption that courts can costlessly determine the shipper's type ex post in determining consequential damages. These assumptions can be justified if the carrier does not learn the shipper's type ex post but, like the court, can only learn it by incurring significant costs. If the parties write a contract contingent on the shipper's type, the verification costs would be incurred even if breach does not occur. In the absence of breach, the shipper would always claim to be the type that pays less, while in case of breach, the shipper would claim to be the type that receives the higher damages. Verification with sufficient probability of success would be necessary to deter the shipper from lying.

However, if only the damages depend on the type, the verification costs would be incurred only if there is breach. It is plausible that verification costs would be lower if there were a breach than if there were no breach. Lost profits may be verifiable, but would certainly be costly to determine. We do not model the 
Johnston was the first to point out that the form and size of contractual inefficiencies depend crucially on the incidence of market power. ${ }^{43}$ In the foregoing model, for example, strategic inefficiencies disappear if shippers instead of carriers are given the power to make "take-it-or-leave-it" offers. ${ }^{44}$ If shippers have market power (and it is costless to contract around the default rule), they will have no strategic incentive to refrain from revealing their type because the carriers no longer use this information to extract consumer surplus (i.e., price above marginal costs) ${ }^{45}$ In that case, high- and low-value shippers would simply offer contracts that give them fully compensatory damages and consequently induce efficient precaution. ${ }^{46}$

Johnston's article, however, gives the mistaken impression that strategic inefficiency will be greater when a Hadley-like default rule restricts awards to foreseeable damages. Yet, if carriers can costlessly contract around a known default, they will offer the same separating menu regardless of the initial default rule. Given their asymmetric information, the separating menu maximizes their profits (even though it is socially inefficient), and they will costlessly contract for it whether or not the Hadley default rule is in place.

\section{Restricting Contractual Freedom to More Efficiently Separate or Pool}

The inefficiency of the separating menu also highlights the diverse forms that strategic bargaining can take. Johnston stresses that high-value shippers will strategically refuse to contract around a Hadley limit on consequential damages and hence inefficiently "pool" with low-value shippers. ${ }^{47}$ Our menu example extends this insight by showing that even when carriers can induce separation, the shipper's strategic reluctance to separate can make the separation process inefficient. The strategic bargaining caused by asymmetric information can thus lead to either inefficient separation or inefficient pooling. ${ }^{48}$

court's verification costs explicitly, but if those costs are significant, consequential damages would look less appealing.

43. We suggested a similar strategic incentive in our analysis of Victor Goldberg's suggestion that courts deny "recovery for lost profits in the absence of explicit contract language to the contrary." Victor P. Goldberg, An Economic Analysis of the Lost-Volume Retail Seller, 57 S. CAL. L. REV. 283, 291 (1984). We concluded: "By [contracting around this default to recover] their profits, retailers may simultaneously reduce their bargaining power. Even Goldberg's penalty default, therefore, could be too weak to induce information disclosure." Ayres \& Gertner, supra note 1, at 105.

44. It is standard in the game theory bargaining literature to allocate bargaining power by giving one side the power to make "take-it-or-leave-it" offers. See Johnston, supra note 1, at 629.

45. When there are costs of contracting, however, high-value shippers may be reluctant to reveal their type. See Ayres \& Gertner, supra note 1, at 110-11; supra note 27.

46. The contracts would offer a price that would only compensate the carrier for the cost of taking this precaution; thus, the carrier would earn zero profits.

47. Johnston, supra note 1 , at 637.

48. In our specific model, when transaction costs are zero, a carrier with market power will always find it profit maximizing to separate. In fact, when the valuation of high-value shippers becomes sufficiently high, the carrier will separate to the point of completely excluding low-value shippers by only offering contracts to high-value shippers. Recall that in our example the carrier had to offer the low-value shipper $\$ 50$ in insurance to prevent high-value shippers from accepting the low-value contract, i.e., pooling. As the 
The fact that default choice does not affect the contractual equilibrium when it is costless to contract does not, however, mean that contract law is irrelevant absent transaction costs. Because contract failure can persist even when there are zero transaction costs, legal limits on contractual freedom may in some circumstances mitigate the strategic inefficiencies. ${ }^{49}$ Restrictions on freedom of contract can take the form of immutable rules (which cannot be contracted around) or rules that prohibit certain types of contractual obligations. Rules of the latter type often take the form of "single-sided" immutable rules, which establish ceilings or floors for one type of contractual obligation. ${ }^{50}$ For example, the good faith doctrine ${ }^{51}$ in contract law and the corporate opportunities doctrin $e^{52}$ in corporate law establish minimum fiduciary requirements for contracting parties and corporate agents respectively. Yet these single-sided immutable rules can be, and are at times, enhanced by private contract. ${ }^{53}$

The current debate about restricting freedom of contract often only considers the use of immutable rules to correct contractual failure by moving the contractual equilibrium to a more efficient, enforced pool. ${ }^{54}$ Restrictions on

high-value shippers' valuation increases above $\$ 150$, the carrier will have to progressively offer less than $\$ 50$ in insurance to the low-value shipper to prevent high-value shippers from pooling. At a sufficiently high valuation, high-value shippers will pool in any contract offered to low-value shippers. Hence, at this point, the carrier has to decide whether a pooling contract will be more profitable than a contract that only serves high-value shippers. As our model indicates, the carrier will choose the latter option because it allows the carrier to exploit its market power over high-value shippers to earn more profits. It should be noted that this is a separating equilibrium because the carrier divines the shipper's type by discovering whether or not it accepts this contract.

Although we do not model the offers and counteroffers that describe bargaining when neither side has the ability to make take-it-or-leave-it offers, we believe that many of the insights carry over into this context. The only way to get a high-value shipper to reveal its type is for the carrier to commit to a contract that does not extract all of the high-value shipper's surplus should it reveal this information. In addition, damages may still be a useful tool to signal one's type or screen between types. The exact form of the contracts and conditions under which separation occurs may well differ from our model, but the basic notion will still hold that the unwillingness of high-value shippers to reveal their type may lead to (1) separation with inefficient reliance, (2) separation with inefficient service of only high-value shippers, or (3) pooling with inefficient reliance.

49. For example, when $v_{h}=150, v_{l}=100$, and $\alpha=.6$, the carrier will separate by offering the menu of contracts $(p=143.75, d=150)$ and $(p=34.4, d=25)$. If the carrier is serving 500 high- and low-value shippers, this will produce total gains from trade of $\$ 38,130$. Under these circumstances, however, legal rules restricting freedom of contract can increase social welfare. An immutable rule that limited consequential damages to the more foreseeable low-value amount would produce gains from trade of $\$ 40,000$, and an immutable rule that allowed consequential damages would produce $\$ 42,250$. Imposing an immutable rule can thus generate an $11 \%$ increase in social welfare because of the divergence between social welfare and the carrier's objective of maximizing profits.

50. The concept of "single-sided" immutability was first discussed in Ian Ayres, Analyzing Stock Lockups: Do Target Treasury Sales Foreclose or Facilitate Takeover Auctions?, 90 COLUM. L. REV. 682, 709-10 (1990). Legal rules governing covenants not to compete also exhibit this quality because the parties cannot contract beyond ceilings in years or dollars respectively. Id. at 710 .

51. RESTATEMENT (SECOND) OF CONTRACTS \$ 205 (1981).

52. RESTATEMENT (SECOND) OF AGENCY $§ 388$ (1958).

53. Some corporations contract for additional obligations from their employees to turn over any opportunities (including any patentable ideas) gained during the time of their employment, thus enhancing the minimum requirements of the corporate opportunities doctrine.

54. Consider, for example, the debate about whether to impose mandatory health insurance. The adverse selection of healthy people refusing to buy (and thus separating from the insurance pool) might cause the insurance market to unravel. See RASMUSEN, supra note 33, at 196 ("adverse selection is an argument for 
freedom of contract-particularly the use of single-sided immutable rules-can, however, also move the contractual equilibrium to more efficient forms of contractual separation. Johnston's article, for example, shows how placing a cap on contractual damages can, under certain conditions, generate more efficient separations. ${ }^{55}$

In the Hadley model, if the proportion of high-value shippers becomes sufficiently large, the carrier may find it more profitable to ignore the presence of low-value shippers and simply offer a monopoly price contract that only the high-value shippers will accept. ${ }^{56}$ This monopoly contract would maximize the carrier's profits by setting both the contract price and damages equal to the value of the high-value shipper. In this equilibrium, the gains from trade in selling to any low-value shippers are foregone. ${ }^{57}$ If, however, contract law imposed a ceiling on damages that was less than the value of the high-value shippers, the monopolist would not be able to make as much money from serving just the high-value shippers. ${ }^{58}$ Requiring inefficiently low damages with regard to the high-value shippers thus reduces the profits of only serving this segment of the market. The imposition of a single-sided immutable rule capping the maximum allowable damages can therefore eliminate the carrier's incentive to ignore low-value shippers. ${ }^{59}$ This liability ceiling exemplifies how a single-sided immutable rule can improve the efficiency of the contractual equilibrium by moving from a less efficient separating equilibrium (in which carriers only contract with high-value shippers) to a more efficient separating equilibrium (in which both high-value and low-value shippers are served).

At the most general level, strategic bargaining (and other causes of contractual failure) can result in either inefficient separation or inefficient pooling of heterogeneous contracting types. As shown in Figure 2, contractual rules can

government enforced pooling"); see also Ayres, supra note 18, at 1316.

55. See Johnston, supra note 1, at 663-64. This liability ceiling is a single-sided immutable rule because shippers and carriers can contract for reduced liability but not for higher liability. For a similar example, see Aghion \& Hermalin, supra note 35, at 388.

56. Even though the contract would be offered to all shippers, only the high-value shippers would find it beneficial to accept. In the initial contractual menu, the carrier offered a less than monopoly price in Alternative 1 to deter high-value shippers from accepting Alternative 2 (which was geared toward low-value shippers). The ability of the carrier to commit contractually to not raising its price after finding out the identity of the high-value shippers plays a crucial role in the success of menus in generating contractual separation and is discussed more fully in the Appendix, infra.

57. The markets for videocassette movies and academic books present many attributes of this model. Video rental stores and libraries are high-value buyers, while individuals are low-value buyers. If the proportion of low-value buyers is small, the sellers prefer to forgo these sales and charge a $\$ 70$ price which only the video stores and library will pay. If the proportion of low-value buyers is large, however, the sellers profit more by forgoing the monopoly markups to the high-value buyers and instead charge a $\$ 20$ book or cassette price to both high- and low-value buyers.

58. The liability cap would force the carrier to take an inefficiently low level of precaution with respect to high-value shippers, and consequently the high-value shippers' willingness to pay would fall more than would the carrier's cost savings for taking the lower level of precaution.

59. This possibility is shown graphically in Johnston's Appendix D. Johnston, supra note 1, at 661 . 
respond to these inefficiencies by generating either more efficient pooling or more efficient separation.

FIGURE 2. Legal Responses to Contractual Failure

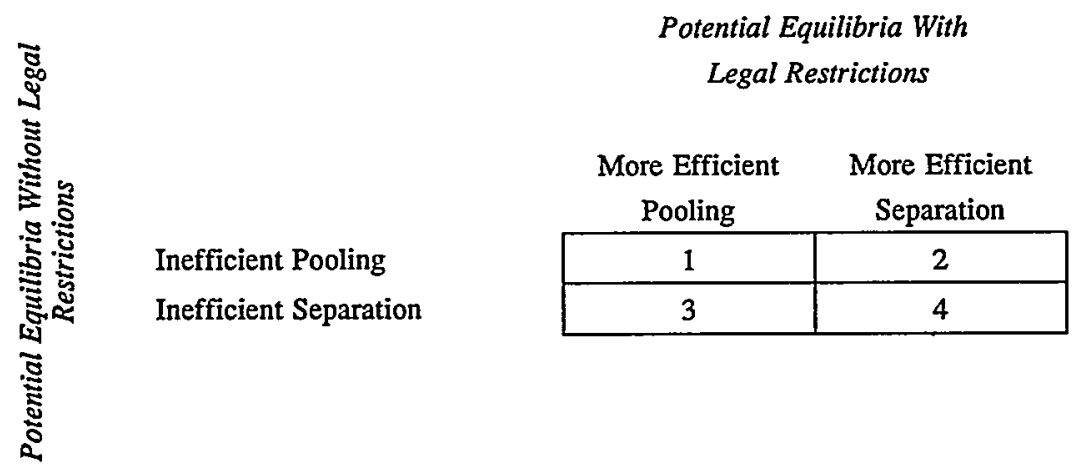

Traditional (i.e., double sided) immutable rules create "pooling" equilibria because all parties must include the rule. Accordingly, immutable rules are represented in the left-hand column (quadrants 1 and 3). Replacing default rules with such immutable rules could potentially enhance welfare by displacing inefficient pooling (quadrant 1$)^{60}$ or inefficient separation (quadrant 3) ${ }^{61}$ This part has argued, however, that policymakers could at least theoretically enhance welfare by inducing more efficient separation. The use of single-sided immutable rules to restrict freedom of contract, represented in the right-hand column (quadrants 2 and 4), could enhance efficiency in cases of either inefficient pooling or inefficient separation. The use of a liability ceiling, for example, might induce separation. ${ }^{62}$ The use of the liability ceiling in the Hadley model is an example of the fourth quadrant because the ceiling moved an inefficient separating equilibrium to a more efficient form of separation. Various forms of immutable rules (single-sided or otherwise) can potentially enhance welfare in any one of the boxes.

The goal of structuring efficient contract law is to identify the source and form of potential contracting inefficiencies and to assess whether legal rules can improve social welfare. This part has shown that contracting inefficiencies

60. For example, Johnston's suggestion that high-value shippers might refuse to contract around the Hadley rule suggests an inefficient pooling that might be mitigated (as in quadrant 1) if contract law imposed an immutable rule awarding consequential damages.

61. We suggested, see supra note 49 and accompanying text, that strategic bargaining in the Hadley context might lead to inefficient separation which might be mitigated (as in quadrant 3 ) if contract law imposed an immutable rule awarding consequential damages.

62. We presented a model in Ayres \& Gertner, supra note 1 , in which a consequential damages default rule might cause high- and low-value shippers to pool inefficiently, but this inefficiency might be replaced with more efficient separation (as in quadrant 2) under the Hadley default. 
can persist even when it is costless to contract around a particular default and that these inefficiencies can potentially lead to either inefficient pooling or inefficient separation.

While in many cases government interventions will be institutionally incapable of mitigating these inefficiencies, this part has provided theoretical examples in which restrictions on freedom of contract can enhance welfare. Moreover, these restrictions need not induce pooling. Some restrictions that impose immutable ceilings or floors can, at times, mitigate inefficiencies by generating a separating equilibrium with higher gains from trade. ${ }^{63}$ Unfortunately, it is unlikely that lawmakers will be able to determine when restricting contractual freedom will enhance the total gains from trade. As shown in the next section, choosing efficient legal rules becomes even more complex when there are costs of contracting, even if these costs are small. Thus, while singleand double-sided immutable rules can enhance efficiency, there are severe practical concerns with these types of restrictions on freedom of contract.

\section{RElAXING the AsSUMPTION OF COSTLESS CONTRACTING}

The last part argued that when contracting is costless and parties have common knowledge of the default rule, the choice of default rules will have no impact on either the equilibrium of contractual obligations or social welfare. In such a world, law could only affect and potentially enhance welfare by restricting freedom of contract with immutable rules. The potential role for law is even larger, however, when contracting around defaults is not costless. The introduction of these costs can have dramatic effects on the type and number of contracts that are made and on the social efficiency of contracting. Even with small contracting costs, the choice of a default can influence the social gains from trade. Thus, without placing immutable restrictions on freedom of contract, policymakers can influence the contractual equilibrium and social efficiency by enlightened selection of obligational gap-filling rules.

Consider again the simple asymmetric information model of Hadley $v$. Baxendale, in which the carrier has the market power, but the shippers have private information about how much they value performance. We showed that if contracting around a default is costless, the carrier would offer either (1) a menu of contracts (that induced high- and low-value shippers to separate), or (2) a single contract (that only high-value shippers would accept), depending on the potential profits from serving only high-value shippers. ${ }^{64}$ Now consider

63. Even traditional immutable rules can, at times, induce contractual separation. In the Hadley context, for example, carriers might respond to an immutable rule awarding consequential damages by offering a price that only high-value shippers will accept. High-price offers of this sort separate shippers simply by their decision to contract.

64. The carrier will choose to serve only high-value shippers (by offering a single, high-priced contract) whenever the proportion of high-value shippers or their value of performance is sufficiently high. See infra Appendix; supra notes 48,56 and accompanying text. 
the effect of introducing costs of contracting around a default damage rule. For simplicity, consider the Hadley "foreseeable" default rule that only awards the more foreseeable low-value consequential damages, and an alternative "consequential" default rule that awards low- and high-value shippers their actual consequential damages. In the Appendix, we analyze the effects of assuming that carriers incur a cost of $c_{d}$ in making an offer that contracts around the default damage rule and a cost of $c_{m}$ in offering a menu of contract offers. ${ }^{65}$

Introducing even modest costs of contracting dramatically increases the complexity of analysis. Figure 3 shows the carrier's profits from offering various types of contracts under a foreseeable damages default. As before, we assume that the value of performance for a low-value shipper is $\$ 100$, and that half of all shippers are the low-value type. In addition, the costs of contracting around a default, $c_{d}$, and the costs of offering a menu, $c_{m}$, are each assumed to be two dollars - so that to offer a menu of contracts with liquidated damages clauses would cost four dollars. On the horizontal axis, the value of performance for the high-value shippers varies between $\$ 100$ and $\$ 180$. Varying the value of performance for the high-value shippers illustrates the importance of the information asymmetry to the carrier. ${ }^{66}$ The vertical axis then measures the profits that the carrier will earn from three different types of contract offers when the carrier is contracting in the shadow of a foreseeable damages default. As shown formally in the Appendix, there are three potential types of offers that might maximize the carrier's profits under a foreseeable default:

(1) a "pooling" offer which will be accepted by both high- and low-value shippers;

(2) a "menu" of offers which induces high- and low-value shippers to accept different contracts; and

(3) an "excluding" offer which only the high-value shippers would accept. ${ }^{67}$

65. We assume that offering a menu involves both transaction costs, $c_{d}$ and $c_{r 2}$. See infra Appendix. We assume that these costs are incurred whether or not the offer is accepted.

66. When the value of performance for high-value shippers become close to that of low-value shippers (here $\$ 100$ ), the carrier's gains from learning the shipper's type (and then price discriminating) become small. Varying the proportion of high-value shippers also determines the importance of the information asymmetry. A similar sawtoothed graph can be constructed varying this proportion along the horizontal axis.

67. An excluding offer also induces separation, because in equilibrium the high- and low-value shippers act differently (only high-value shippers accept), thus revealing all shippers' types to the carrier. 
FIGURE 3. Carrier Profits Using Different Contract Offers Under Foreseeable

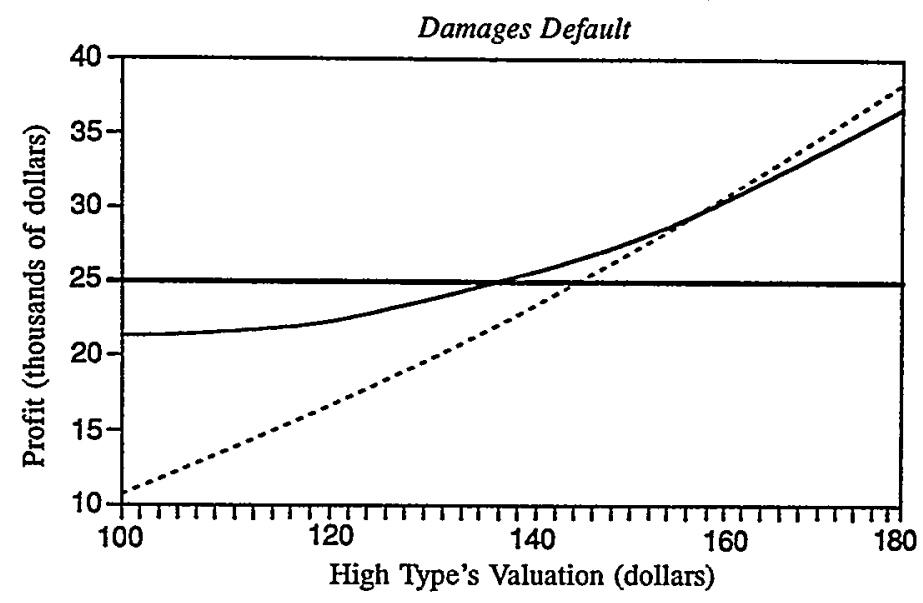

\begin{tabular}{|ll}
\hline Pooling Offer $\quad-$ Separating Menu & - Excluding Offer
\end{tabular}

As Figure 3 illustrates, these different types of contracts maximize the carrier's profits for different ranges of high type valuation. When the high-value shipper has a relatively low valuation $\left(v_{h}<140\right)$ the asymmetric information is relatively unimportant because the difference between the high and low valuation $\left(v_{l}=100\right)$ is small. In this range, the potential profits from price discrimination are not worth the transaction costs of offering a menu to separate the high- and low-value types. It is even less profitable to set a price which only the high-value shippers will accept, because the low-value shippers are willing to pay almost as much as the high-value. In this situation, the carrier will profit most by offering a contract which efficiently exploits low-value shippers $(P=100, D=100) .{ }^{68}$ High-value shippers will accept this offer as well (thus pooling with low-value shippers). Although this contract induces inefficient precaution for high-value shippers, they will nevertheless accept the offer because, through the pooling offer, the carrier commits to a price lower than the high type's value.

For an intermediate range of high type valuations $\left(140<v_{h}<160\right)$, the separating menu of offers becomes the most profitable. When the shippers' valuation is relatively high, the potential profits from discriminating between high- and low-value shippers outweigh the costs of contracting $\left(c_{m}=\$ 4\right)$. The carrier will offer the same menu of alternatives as described in the costless contracting world. ${ }^{69}$

68. The carrier profit line for the pooling offer is horizontal because the maximum contract price is unaffected by the high type's valuation. The pooling price cannot go above $\$ 100$ if low-value shippers continue to accept the offer.

69. See supra text accompanying notes $32-33$. 
Finally, when the high-value shipper has a relatively high valuation $\left(v_{h}>\right.$ 160), the carrier will maximize profits by making an "excluding" offer. This type of offer efficiently exploits the high-value shipper by setting both the contractual price and damages equal to the high-value shippers' valuation $(P$ $=D=v_{h}$ ). This offer is only accepted by the high-value types and thus excludes low-value shippers from contracting. For this range of high type valuations, the carrier would need to provide more drastic forms of "carrots" and "sticks" to induce the high-value shippers to separate. ${ }^{70}$ The carrier's costs of inducing separation outweigh the costs of excluding low-value shippers and simply exploiting market power against the high-value shippers. The equilibrium carrier profits under the foreseeable damage default, for different high type valuations are just the highest points for the three segments in Figure 3.

This analysis of carrier profits under a foreseeable damages default is quite distinct from an analysis of social welfare induced by the different types of contracts, because it excludes the consumer surplus enjoyed by high- and lowvalue shippers under various contracts. The carrier is assumed to make the offer which maximizes its private profit, not the offer which maximizes the total gains from trade. The total gains from trade will be a total of the seller profits (the carrier's gain) and the consumer surplus (the shippers' gain).

Figure 4 provides an analogous graph of the equilibrium consumer surplus for high- and low-value shippers under the foreseeable damages default. Because this is only an equilibrium analysis, the three segments correspond to the three different types of contractual offers that will be profit maximizing for different ranges of high type valuation. The most striking result of Figure 4 is that the low-value shippers receive, at most, infinitesimal gains from trade under any of the equilibrium contract types. Under a pooling contract, a lowvalue shipper receives only an infinitesimal benefit from contracting because the carrier selects the offer that efficiently extracts all of the low-value shipper's surplus. Similarly, under a separating contract, a low-value shipper receives only an infinitesimal benefit from contracting because the carrier separates by offering low-price and low-damage contracts that make low-value shippers only slightly better off by accepting. ${ }^{71}$

70. As the high type valuation increases, high-value shippers have increasing incentives to pool with the low-value shippers and thus avoid the exploiting price discrimination of the separating menus. To deter this pooling, the carrier must reduce the attractiveness of the low-value offer by further reducing the contractual damages ( $D_{1}$ decreases) and increase the attractiveness of the high-value offer by increasing the high type consumer surplus ( $V_{t} / P_{h}$ increases).

71. Separation is accomplished by offering an inefficiently low damages $\left(D_{l}<v_{l}\right)$ and price pair that is on (or just above) the low-value shipper's zero-surplus indifference curve. See supra text accompanying note 38 . 
FIGURE 4. Equilibrium Shipper Surplus Under Foreseeable Damage

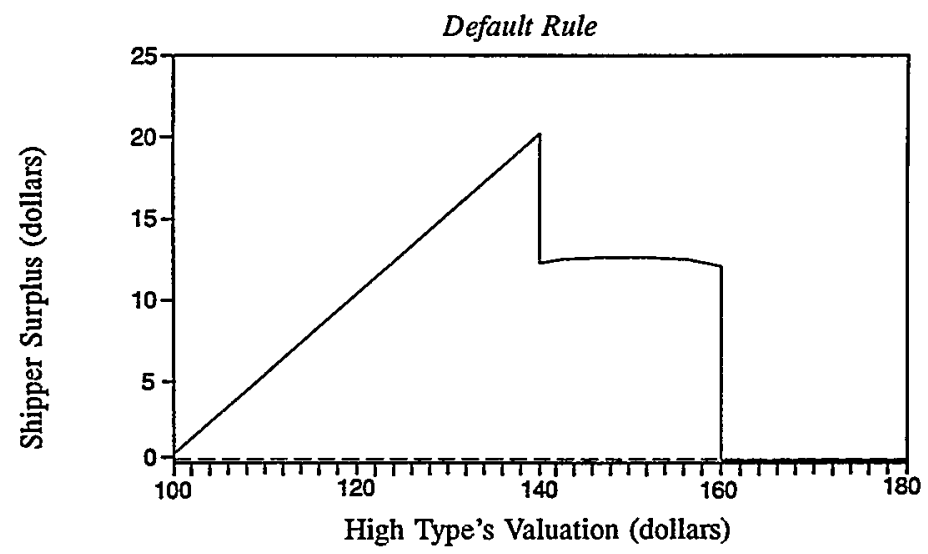

High-Value Surplus

---- Low-Value Surplus

A high-value shipper captures its largest surplus when the carrier makes pooling offers because the offer is geared to exploit the low-value shippers and let high-value shippers earn substantial informational rents. A high-value shipper earns intermediate surplus when the carrier offers a menu of contracts. Splitting the gains from trade with the high-value shipper is the "carrot" that helps induce the high-value shipper to reveal its type. Finally, neither highvalue nor low-value shippers have any consumer surplus when the carrier makes an excluding offer. The low-value shippers earn nothing because they fail to contract; the high-value shippers earn only infinitesimal surplus because the carrier's excluding offer efficiently extracts all the gains from contracting.

Graphs similar to Figures 3 and 4 could also be drawn under a consequential damages default to depict the carrier's profits and the consumers' surplus for different types of contracts. Under a consequential damages default, lowvalue shippers would continue to earn only infinitesimal returns from contracting-so that the gains from trade would be split solely between the high-value shippers and the carrier. ${ }^{72}$ The profit-maximizing contracts would have a similar ordering:

$\begin{array}{lll}v_{h} \longrightarrow & \\ \text { Pooling equilibrium: } & \text { Separating (menu) } & \text { Separating (exclusion) } \\ \text { not worth transaction } & \text { equilibrium: worth } & \text { equilibrium: not } \\ \text { costs to separate } & \text { transaction costs to } & \text { worth serving low- } \\ & \text { separate } & \text { value shippers }\end{array}$

72. As before with a foreseeable default, low-value shippers earn next to nothing from pooling and separating offers and nothing from excluding offers. 
When high type valuations are low (i.e., close to low type ones), carriers will make a pooling offer-because the gains from discriminating between the high and low types is outweighed by the costs of contracting. When high-type valuations are intermediate, carriers will offer separating menus-because the gains from discriminating between the high and low types is now greater than are the costs of contracting. Finally, when high-type valuations are high, carriers will make excluding offers-because it is more profitable to exploit efficiently the high-value shippers than to serve both types of shippers.

At this level of generality, both foreseeable and consequential damage defaults will induce the same progression of carrier offers (from pooling to separating to excluding) as the high type valuation increases. There are, however, important differences between a foreseeable default and a consequential default. Carriers will choose to make pooling, separating, and excluding offers for different ranges of high type valuations, depending on the initial default. Moreover, the different defaults will generate disparate amounts of carrier profits and consumer surplus (for high-value shippers)- - so that the net gains from trade will vary under the alternative legal rules. When contracting around a default is costly, a default rule can potentially generate inefficiency by inducing inefficient precaution, inefficient failure to deal with low-value shippers, or inefficient transaction costs. ${ }^{73}$ For given values of the underlying parameters (such as the size of the high type's valuation or the proportion of high types in the population), the default that minimizes these three potential inefficiencies will produce the largest social welfare (i.e., gains from trade).

Figure 5 shows the relative efficiency of the consequential and foreseeable damages defaults. As before, the valuation of high type shippers varies on the horizontal axis. Now, however, the vertical axis measures not just the carrier profits (as in Figure 3) or the consumer surplus (as in Figure 4), but the total gains from trade under each default. ${ }^{74}$ The dashed line represents the total gains under a foreseeable damages default, which is simply the sum of the carrier profits for the most profitable contracts in Figure 3 and the consumer surplus in Figure 4. The solid line represents the net gains from trade under a

73. Johnston's basic model, in contrast, does not allow for any of these inefficiencies. See Johnston, supra note 1. His argument that consequential damage defaults are more efficient, therefore, cannot be sustained. Even if one accepts his conclusion that a consequential damages default will induce separation and that a foreseeable damages default will induce pooling, absent transaction costs, differences in precaution levels, or differences in the number of shippers served, there would be no difference in the relative efficiency of the two defaults.

74. We should reemphasize that this Article is geared towards efficiency-minded lawmakers. Hence, in computing "net gains from trade" on the vertical axis, we simply add shipper gains from trade and carrier gains from trade. By using this measure of "social welfare," however, we are assuming that one dollar of carrier surplus (profits) should be considered equivalent to one dollar of shipper surplus. In other words, this measure of social welfare ignores issues of income distribution by focusing on the gains from trade, regardless of which party benefits from the gain. As emphasized below, however, our primary result that lawmakers will have difficulty choosing the "best" rule does not rest on our analysis of efficiency. The number of diverse equilibria will make it just as difficult for lawmakers to pursue other than efficiency-based norms. See infra note 114 and accompanying text. 
consequential damages default for various valuations by the high type. For a given high type valuation, one default is efficient if it produces greater gains from trade.

FIGURE 5. Net Gains From Trade Under Alternative Default Rules Varying High Type's Valuation

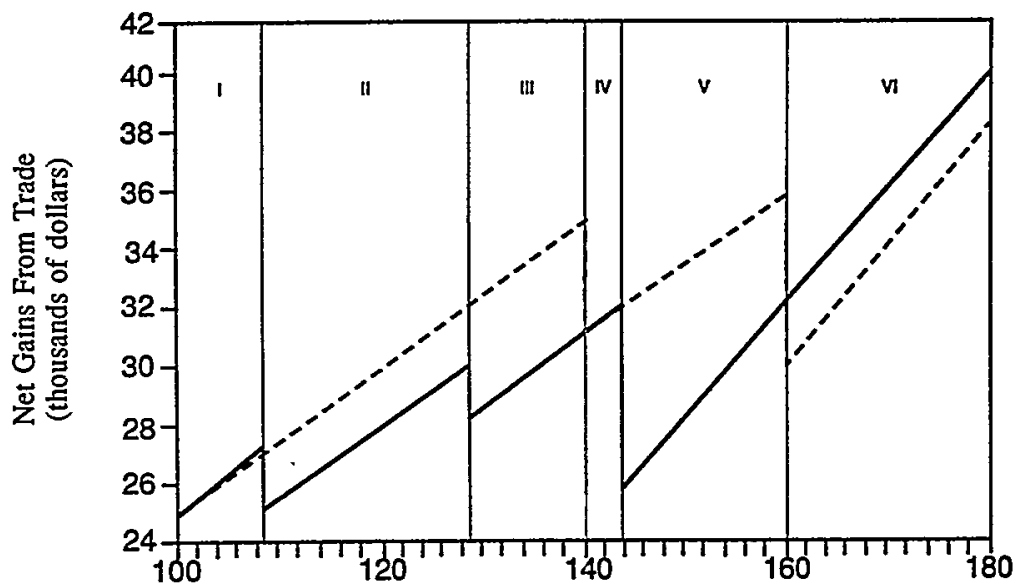

High Type's Valuation (dollars)

\begin{tabular}{|cll||}
\cline { 2 - 3 } \multicolumn{1}{c}{} & \multicolumn{2}{c}{ Consequential } \\
\hline Segment & Default Rule & Equilibrium Contract \\
\hline \hline I & Consequential & Serve both types, default damages \\
I & Foreseeable & Serve both types, default damages \\
\hline II & Consequential & Serve both types, foreseeable damages \\
II & Foreseeable & Serve both types, default damages \\
\hline III & Consequential & Serve both types, separating menu \\
III & Foreseeable & Serve both types, default damages \\
\hline IV & Consequential & Serve both types, separating menu \\
IV & Foreseeable & Serve both types, separating menu \\
\hline V & Consequential & Serve high type only, default damages \\
V & Foreseeable & Serve both types, separating menu \\
\hline VI & Consequential & Serve high type only, default damages \\
VI & Foreseeable & Serve high type only, default damages \\
\hline
\end{tabular}

As shown in Figure 5, the introduction of transaction costs increases the number of potential contractual equilibria, with the different defaults generating divergent degrees of efficiency. Each discontinuity in total gains from trade represents a shift in the type of contract offered by the carrier. For example, as the value of performance for the high-value shipper increases to just below $\$ 160$, a foreseeable damages default will cause the carrier to change from offering a separating menu to offering a single, high-priced contract that only 
high-value shippers will accept. In models with symmetric information, producers maximize profits by setting prices so that marginal costs equal marginal revenues. In this asymmetric information model, however, the carrier maximizes profits by comparing the profits of several different types of contracts and choosing the type with the highest profits. Figure 5 shows the profit-maximizing contracts for the two different defaults and for different high type valuations. In all, the introduction of contracting costs creates the potential for seven different contractual equilibria with different attendant welfare levels. ${ }^{75}$

Before analyzing the specific ways that strategic bargaining generates multiple equilibria, the most dramatic lesson to draw from Figure 5 is the difficulty of choosing the efficient default. In this model of Hadley (where shippers have private information and carriers make take-it-or-leave-it offers), consequential damages defaults are efficient when the value of performance for high types is either large or small, but for intermediate values the foreseeable damages default is efficient. Moreover, the choice of default is important. If the value of performance for the high type is $\$ 150$, choosing the inefficient default sacrifices $30 \%$ of the total social gains from trade. Furthermore, this

75. When contracting around a default is costly, the two defaults can generate the following seven separating or pooling equilibria:

Separating Equilibria

(1) carrier offers separating menu, which both types of shippers accept (inefficient precaution for low-value shippers and efficient precaution for high-value shippers);

(2) carrier offers high-priced contract with default of consequential damages, which only high-value shippers accept (inefficient exclusion of low-value shippers);

(3) carrier offers high-priced contract with default of foreseeable damages, which only high-value shippers accept (inefficient exclusion of low-value shippers and inefficiently low precaution for high-value shippers);

(4) carrier offers high-priced contract that contracts around foreseeable damage default and expands damages to consequential damages standard, which only high-value shippers accept (inefficient exclusion of low-value shippers);

Pooling Equilibria

(5) carrier offers low-priced contract with default of consequential damages, which both types of shippers accept (average precaution in pooling equilibrium);

(6) carrier offers low-priced contract with default of foreseeable damages, which both types of shippers accept (inefficiently low precaution for high-value shippers); and

(7) carrier offers low-priced contract that contracts around consequential damages default and limits damages to foreseeable lower value, which both types of shippers accept (inefficiently low precaution for high-value shippers).

Due to the costs of contracting, equilibria (3) and (4) imply different welfare levels. This feature also distinguishes equilibria (6) and (7). 
dramatic efficiency loss can occur in contexts where the costs of contracting around defaults are negligible. ${ }^{76}$

The more intricate explanation for the relative efficiency of the two default rules can be gleaned by dividing the horizontal axis of Figure 5 into six segments corresponding to different valuations of performance by the high-value shippers, $v_{h}$.

\section{A. The Extreme Cases of Pooling and Exclusion Under Either Rule: Segments $I \& V I$}

The consequential damages rule is the more efficient default rule for high and low values of $v_{h}$ (segments I and VI of Figure 5) in situations in which the carrier is not going to contract around either rule (segment I) ${ }^{77}$ or the carrier is only going to serve the high-value shipper (segment VI) ${ }^{78}$ When the carrier is not going to contract around either default, the consequential damages standard is the more efficient default rule because the carrier takes more efficient precautions than it does when damages are limited to the lower foreseeable standard. ${ }^{79}$ When the carrier is only going to serve the high-value shipper, the consequential damages standard is again the more efficient default rule, because it induces efficient carrier precautions without any costs of contracting. ${ }^{80}$

76. The choice of a fully efficient contract regime is even more difficult. As before, efficiency-minded lawmakers would need to consider that restrictions on freedom of contract could produce superior equilibria to the "simple" choice of a default. Indeed, in this model of Hadley, with costs of contracting, it is possible for legal restrictions on contract to produce, at times, more efficient pooling and separation. For example, assume that the value of performance for the high-value shipper is 145 , and that there are 500 high- and low-value shippers. Under these assumptions, an immutable rule of foreseeable damages produces gains from trade of $\$ 36,250$, compared to $\$ 32,250$ under a foreseeable damages default, or $\$ 26,280$ under a consequential damages default. In this circumstance, imposing an immutable rule can increase social welfare by more than $12 \%$ over the most efficient default.

77. When $v_{h}$ is sufficiently low, the carrier does not find it worth the transaction costs to try to distinguish between high- and low-value shippers, because the gains from price discrimination are small.

78. When $v_{s}$ is sufficiently high, a carrier maximizes profits by charging a price that only high-value shippers will accept. The profits from making offers that fully exploit the high type (and that low types reject) are greater than the profits from either offering a menu or offering a contract that both types will accept. The profits from exercising market power against the high-value shippers are sufficiently great that the carrier simply ignores the presence of the low-value shippers in making its high-price offer. See supra note 38 and accompanying text.

79. When the carrier fails to contract around a consequential damages default, the carrier will take precautions for the expected damages (which is first best, conditional on the carrier's ignorance of seller type).

80. Under a foreseeable damages default standard, the carrier would either take inefficient precaution (because damages are limited to low valuation) or contract for higher damages and incur inefficient contracting costs.

This argument, however, turns crucially on how foreseeability is defined when only the high-value shipper is served. If carriers ignore low-value shippers by offering high-price contracts, then courts might find that the higher valuation was foreseeable. Thus, if a videocassette manufacturer prices its videocassette in the $\$ 70$ range knowing that the mass of low-valuing individuals will not buy it, courts might hold it liable for the higher consequential damages that might accrue if shipment is to a video rental store is delayed. See supra note 57. 


\section{B. The Complexity of Intermediate Valuations: Segments II-V}

The intermediate segments in which the foreseeable damages default produces more efficient results reveal more interesting (and more complex) aspects of the strategic inefficiencies of asymmetric information. ${ }^{81}$

\section{The Greater Likelihood of Inefficient Separation Under a Consequen- tial Damages Default: Segment III}

In segment III, the consequential damages rule induces the separating menu of offers discussed above, while the foreseeable damages rule causes the carrier to offer the default damages and a low price that both shipper types will accept. This accords with Johnston's conclusion that a consequential damages default more easily induces contractual separation than a foreseeability default. ${ }^{82}$ Johnston, however, wrongly concludes that the consequential damages default is a more efficient rule. ${ }^{83}$ The carrier induces contractual separation by committing to inefficient precaution for the low-value shippers. As shown in Figure 5 , this precaution inefficiency for contracts with low-value shippers, plus the transaction costs of offering the separating menu, make the contractual equilibrium induced by the foreseeable damages default more efficient. ${ }^{84}$

The higher propensity to separate under the consequential damages default stems from that rule's effect on carrier profits. If the carrier offers a single contract with a price so low that low-value shippers will accept, then high-value shippers will earn rents on their private information by accepting the same contract and pooling with low-value shippers. In this pooling context, the highvalue shippers receive lower effective prices (and carriers receive lower profits) when consequential damages are awarded because the high-value shippers

81. In Figure 5, segment IV represents a narrow range $\left(140<v_{h}<143\right)$ over which both default rules produce the separating menu described supra text accompanying notes 33-38. Because carriers incur equal transaction $\cos t s\left(c_{m}\right)$ under both rules and offer identical contracts, the two defaults produce equally efficient results.

82. Johnston, supra note 1 , at 636-39.

83. Id. at 618,626 .

84. In segment III, the foreseeable damages default induces inefficient precaution for contracts with high-value shippers. This example, however, demonstrates that the separating menu under the consequential damages default rule produces more inefficiencies. For example, if $v_{h}=130$ (and $v_{l}=100, \alpha=0.5$ ) then a carrier serving 500 high- and low-value shippers will produce $\$ 28,300$ from exchange under the consequential damages default (with the separating menu equilibrium), while the foreseeable damages default will generate $\$ 32,500$ from contractual profits. 
receive full insurance for the same price as the low-value shippers. ${ }^{85}$ Consequently, carriers have a greater incentive to separate under consequential damages defaults than they do under foreseeable damages defaults.

\section{The Greater Likelihood of Inefficient Pooling Under a Consequential Damages Default: Segment II}

For low values of $v_{h}$ (when the carrier offers a pooling contract to both types of shippers) the carrier is more willing to contract around a consequential damages default because the carrier earns lower profits from pooling with consequential damages than from pooling with foreseeable damages. The carrier has to bear the higher costs of fully insuring high-value shippers under a consequential damages standard. Pooling equilibria with a foreseeable damages standard is more profitable for the carrier because it does not have to pay full value to high-value shippers in case of breach. The carrier's added costs for full insurance are not needed to induce the high-value shippers to contract, because high-value shippers earn positive surplus on contracts that pool under the foreseeability standard.

When the costs of this full insurance exceed the costs of contracting around the default, it is in the carrier's best interest to bargain around a consequential damages default rule and limit damages to the foreseeable level. The increased profits from reducing the damage liability to the high-value shipper more than outweigh the costs of contracting for limited damages. This explains why in segment II the carrier willingly incurs the transaction costs of contracting around the consequential damages default to limit damages to the foreseeable default level. This also explains why in segment II the foreseeable damages default produces more efficient results-it achieves the same contractual outcome as the consequential default does, without the costs of contracting. ${ }^{86}$

\section{The Greater Likelihood of Inefficient Exclusion Under a Consequential Damages Default: Segment V}

The foreseeable damages default also might be more efficient because it creates better incentives for serving both types. For example, in segment $\mathrm{V}$, the foreseeable damages default induces carriers to offer the separating menu of contracts, while the consequential damages default induces carriers to offer a high-price, default damages contract which only high-value shippers accept. The foreseeable damages for this range of $v_{h}$ are more efficient because the ineffi-

85. When the carrier wants to offer contracts that low-value shippers will accept, it cannot charge higher prices for contracts that provide for higher consequential damages (if incurred) because low-value shippers do not benefit from this higher breach insurance.

86. Accordingly, the difference in social welfare between the consequential damages default and the foreseeable damages default is the cost of contracting, which in segment II is equal to two dollars. 
ciencies of excluding low-value shippers far outweigh the inefficient precaution and contracting costs of the separating menus offered under the foreseeable damage default. ${ }^{87}$ With a foreseeability limitation, the profits from serving only high-value shippers are reduced, because these shippers will not accept as high a price knowing that the carrier will take an inefficiently low precaution. Thus, the carrier will have more of an incentive to contract around this inefficiency in situations (segment $\mathrm{V}$ ) in which it would not contract around a consequential damages default. The inefficiency of the foreseeable damages default makes the rule a "penalty" or "information-forcing" default, which in this context induces efficiency-enhancing separation. ${ }^{88}$

The foregoing analysis graphically demonstrates the difficulty of optimal default choice. For some values of $v_{h}$ (segment III), the foreseeability default is superior because it precludes menu separation; for other values (segment $V$ ), the foreseeability default is superior because it induces menu separation. Once there are even minimal costs of contracting around a default, it becomes difficult to assess whether contractual heterogeneity is a social good, much less whether it is the efficient choice of law.

Moreover, changing the size of these costs of contracting can have perverse, disproportionate effects on welfare that can be either positive or negative. Figure 6 , for example, shows the effects of varying the cost of offering a contract with non-default damages, $c_{d^{*}}{ }^{89}$ The discontinuous movement in social welfare from marginal increases in the costs of contracting exemplifies a standard game-theoretic result: when players interact strategically, changing the underlying structural values by small amounts can induce large changes in equilibrium behavior. ${ }^{90}$

In this strategic context, raising the transaction costs can even increase social welfare. For example, when the costs of offering a non-default damage clause, $c_{d}$, are less than $\$ 0.25$, the carrier would be willing to contract around a foreseeable damages default rule and to offer the separating menu of contracts. When the cost of contracting rises above this value, the carrier will no longer find it profitable to contract around a foreseeability default and will instead offer a single low-price contract, which both shipper types will accept

87. For example, in Figure 5 , when $v_{h}=150$, the total gains from trade under the foreseeable damages rule are $\$ 33,500$, while the gains are only $\$ 28,130$ under the consequential damages rule.

88. Thus, even when the carrier has market power, there are still situations in which the Hadley-like foreseeability default can, as we previously suggested, be an efficient information-forcing default. Ayres \& Gertner, supra note 1 , at 99 .

89. As before, $v_{l}=\$ 100, \alpha=0.5, c_{m}=0.02$, and $v_{h}=130$. The value of $v_{h}$ corresponds to segment II in Figure 5.

90. Using calculus to analyze changes in equilibrium from changes in exogenous underlying variables is thus not possible. See Ayres, supra note 18, at 1313-14; RASMUSEN, supra note 33, at 124. 
and which will create higher total gains from trade. ${ }^{91}$ In short, much like immutable rules, high transaction costs can improve efficiency.

The presence of transaction costs, however, can also perniciously exacerbate the inefficiencies of asymmetric information. Figure 6 also shows that the potential welfare loss from choosing the wrong default is not limited to the costs of contracting around the prevailing default. The potential social loss can be disproportionate to the costs of contracting. Thus, in Figure 6 when the costs of contracting around a default, $c_{d}$, are greater than $\$ 4.12$, the social costs per shipper of choosing the wrong default can be more than $\$ 11$. When contractual behavior is strategic, policymakers can no longer be confident that the social costs of choosing the wrong default are limited to the private costs of contracting for alternative obligations. There may be much more at stake in choosing the wrong default than inducing unnecessary contracting costs.

FIGURE 6. Net Gains From Trade Under Alternative Default Rules Varying

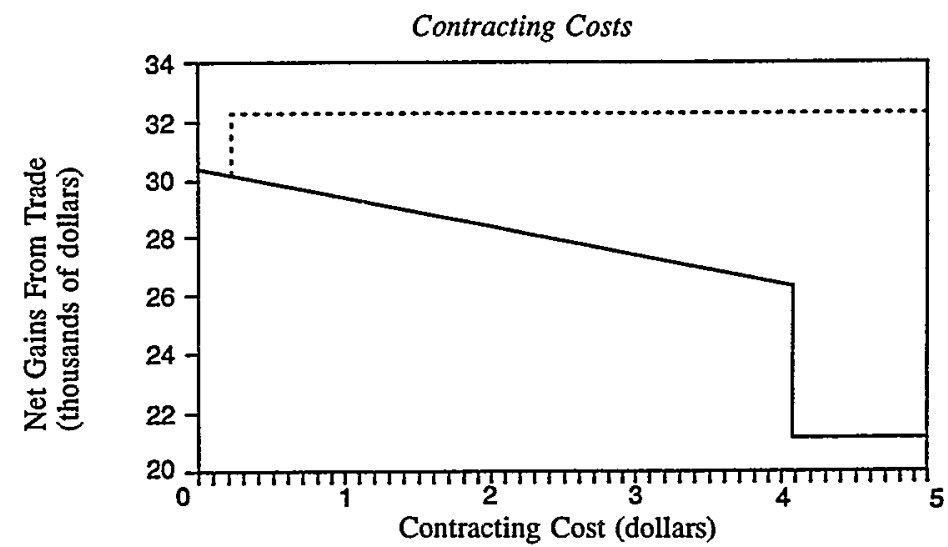

- Consequential --- Foreseeable

The possibility of these alternatively mitigating and exacerbating effects for strategic inefficiency undermines the usefulness of the hypothetical contract approach to setting defaults. That is, an analysis of how parties would contract in the hypothetical world of zero transaction costs cannot provide a useful benchmark for policymaking. First, when costless contracting leads to a separating menu of offers, it is literally impossible to choose a single contract for which the parties would have bargained. Second, the choice of a "majoritarian" default-derived as the contract that most parties would have contracted for

91. The savings in transaction costs and the improved efficiency in precaution for low-value shippers generate higher gains from trade than the separating menu with lower transaction costs. Given that immutable rules can at times increase social welfare, it should not be surprising that increased transaction costs can have a similar effect, because when the costs of contracting around a default are sufficiently high, the default will be effectively immutable. 
absent contracting costs-would produce an inefficient standard that would undercompensate even the low-value shippers. ${ }^{92}$ Regardless of how parties would contract in hypothetical worlds in which contracting is costless, our analysis demonstrates that different legal rules will be efficient as the costs of contracting and other structural variables vary.

We have shown that even small changes in a few underlying variables can cause large changes in the relative efficiency of alternative default rules. Setting an efficient default rule will depend upon precise determinations of underlying variables, a task that is extremely difficult for courts and legislatures. The difficulty of choosing efficient legal rules in our relatively simple model portends a practical indeterminacy for lawmakers confronted with a complex reality. Unfortunately, the problem becomes even more complex when we relax the assumption of common knowledge, as we do in the next part.

\section{ReLAXING the AsSUmption OF COMMON KNOWLEDGE}

We now explore the role of default rules when the assumption that both contracting parties are fully informed about the default rule is dropped. ${ }^{93}$ There are a number of different ways that contracting parties may have incomplete information about a rule of law. A party may not consider that a particular contingency may arise and therefore will not become informed about the appropriate default rule. Even if a party knows that a particular contingency is possible, the contingency may be considered so unlikely that it would not pay to become informed about the rule of law. Finally, a party can simply be misinformed about a default rule, believing that the rule of law is in fact different from what it truly is. ${ }^{94}$

In addition to considering the source of incomplete knowledge about the legal rule, it is useful to distinguish between situations in which the contracting parties are symmetrically informed about the rule and situations in which one party knows the rule and the other does not. If both contracting parties are equally uninformed about a default rule, a number of outcomes are possible. They may bargain over the contingency and draft a contract that specifies what the parties' obligations are in the particular contingency. They may agree either

92. Recall that with costless contracting, the carriers precommitted to inefficiently low damages (of $\$ 50$ relative to the low type valuation of $\$ 100$ ) in order to eliminate the temptation of high-value shippers to pool contractually with low-value shippers. If this inefficiently low amount of damages was chosen as the default, it would produce inferior equilibrium contracting for a broad range of underlying values.

93. In fact, our previous assumption that the default rule is "common knowledge" means that not only is each side informed, but each knows the other is informed, and each knows that the other side knows that each is informed. Common knowledge means that we can apply this recurring cycle of knowledge forever. Randy Barnett has recently analyzed how parties come to know default rules, and he argues that default rules should often (but not always) be chosen to conform with the parties' common sense expectations. See Barnett, supra note 24.

94. Charles J. Goetz, John Monohan, and Bob Scott have recently found that the public has several misperceptions about contractual default rules. Charles J. Goetz et al., Public Knowledge of Contract Law (Aug. 31, 1984) (unpublished manuscript, on file with authors). 
on the default rule of which they are ignorant or some other rule. The choice of default rule is irrelevant in this case because it has no effect on the equilibrium contract or the transaction costs associated with its drafting. Alternatively, the equally uninformed parties may simply fail to negotiate over the contingency. In this case, the default rule will be binding on the parties, and it clearly matters. ${ }^{95}$ By construction, however, the default rule cannot affect the contractual outcome, so the efficient default rule is to choose what the parties would have chosen themselves. ${ }^{96}$

The more interesting case to consider involves contracting parties with different information about the default rule. This asymmetry may be very common in situations in which one party to the contract has repeatedly participated in similar contractual negotiations and the other side has not. ${ }^{97}$ In this environment, the choice of default rule can affect the contractual equilibrium and thereby affect efficiency, even in the absence of transaction costs.

The better informed party may choose to keep silent about the contingency in order to maximize its returns, even if efficiency can be improved by negotiating on the contingency. Consider again our model of Hadley v. Baxendale. Assume that the carrier knows that the default damages rule is foreseeable damages, while there is a chance that the shipper is misinformed and believes that the default damages rule is consequential damages. From our previous analysis, in the absence of transaction costs and common knowledge of the default rule, the carrier will either offer a separating menu of contracts or choose to serve only the high-value shipper with high damages. A high-value shipper who mistakenly believes that she will be compensated for consequential damages under the default rule is willing to pay $v_{k}$. However, because the damages for breach are less, the shipper's actual expected surplus from the contract can be negative..$^{98}$ The carrier may offer high-priced contracts to prey on the mistaken beliefs of high-value shippers when but for this misinformation it would have served both types of shippers.

95. We are assuming that the contract is obligationally incomplete, so that if the parties fail to negotiate over the contingency, the court will fill in the obligational gap. If the contract is contingently incomplete, the court may simply enforce the contract and the default again becomes irrelevant.

96. See Ayres \& Gertner, supra note 1, at 93; supra text accompanying note 16.

97. Many contractual settings satisfy this condition. Intuitively, they may include residential leasing, real estate agent/seller contracts, consumer sales contracts, franchise and dealership agreements, residential construction and repair contracts, insurance contracts, and labor contracts. Barnett, supra note 24, independently analyzes this situation.

98. The possibility that a party uninformed about the true contractual obligations will have a negative expected payoff makes this form of strategic inefficiency analogous to procedural unconscionability. For a discussion of procedural unconscionability, see Richard Epstein, Unconscionability: A Critical Reappraisal, 18 J.L. \& ECON. 293 (1975). With both information asymmetry and procedural unconscionability, the "revealed preference" of the parties for the contract is undermined by our procedural concern that one of the parties did not understand the nature of the contractual commitment. That is, if the party that is asymmetrically informed about the legal default also knows enough about the other side's value of performance, the informed party may know that the mistaken view of the law is a "but for" cause of the transaction. 
Now consider a consequential damages default. If there is some probability that a shipper is misinformed and believes that she will only receive foreseeable damages under the default rule, the carrier cannot take advantage of the shipper's ignorance. The misinformed shipper incorrectly believes she is getting a worse deal than she actually is. The only way the carrier can do as well as when there is common knowledge of the default rule is to contract explicitly for damages, thereby eliminating the shipper's misinformation about what she would receive in case of default.

The point is much broader than the issue of awarding consequential damages and is especially relevant in settings where a repeat player is contracting with a one-shot player. Setting a default rule that least favors the better informed parties creates an incentive for the informed party to bring up the relevant contingency in negotiations. This can signal the uninformed party that the contingency is important and can cause her to become informed about the probability that the contingency will occur. Thus, the default rule can cause the parties to negotiate for explicit terms in the contract, thereby overriding the default.

Explicit negotiation over the relevant contingency can improve efficiency in a number of ways. It allows the parties to allocate risk optimally by choosing a contract which leads to efficient reliance, breach, and renegotiation. If the default rule is set in a manner that favors the informed party, these efficiency gains may not be achieved because the informed party is at a strategic advantage by remaining silent: the fraction of the gains from trade that the informed party gives up by inducing negotiation over the contingency may not be compensated by the increased gains from trade that result from a more efficient contract. As with other forms of strategic inefficiency, a party's superior knowledge of the default rule is private information which can at times generate higher returns if kept private. ${ }^{99}$

The argument for information-forcing default rules is strongest when transaction costs are small. If there are large costs associated with bargaining around a default rule, an information-forcing rule may result in inefficiencies either by parties not contracting around the suboptimal rule or by parties incurring large costs to contract around it. As we have seen before, ${ }^{100}$ the optimal choice of default will involve a variety of tradeoffs when there are costs of contracting.

Even in the presence of significant transaction costs, there are differences between private information about types and private information about default

99. For an example of this phenomenon involving whether the seller or real estate agent gets to keep a buyer's nonrefundable deposit in a real estate sale agreement that the buyer breaches, see Ayres \& Gertner, supra note 1 , at 98 . Since the seller is less likely than the agent to know the default rule, our analysis implies that a default rule that allows the seller to keep the deposit may be justified as a way to force the agent to contract explicitly for the efficient allocation.

100. See supra text accompanying notes 75-78. 
rules. When the asymmetric information is about the default rule, any explicit contracting solves the information problem by making the default rule irrelevant. When the asymmetric information is about types, however, we have seen that explicit contracting may not lead to information revelation and, even if it does, it may not increase efficiency. ${ }^{101}$

\section{CONCLUSION}

This Article has focused on one category of transaction costs-the costs of bargaining around default rules. In analyzing how these costs influence the efficient structure of contract law, we have developed four major results:

When Contracting Around Defaults Is Costless:

(1) strategic inefficiencies can persist even when parties can costlessly contract around known default rules; and

(2) when parties can costlessly contract around a known default, the choice of default will not affect the type or number of contracts that parties make;

When Contracting Around Defaults Is Not Costless:

(3) increasing the costs of contracting around a default a small amount can disproportionately decrease or increase the net gains from trade; and

(4) when parties cannot costlessly contract around a known default, the appropriate choice of default can depend on a variety of underlying variables that are independent of the hypothetical contract that parties would sign in a world without transaction costs.

These conclusions were derived from a simple model of Hadley v. Baxendale. Strategic bargaining under asymmetric information creates the possibility of contractual inefficiency, even if contracting around defaults is costless. Shippers will be reluctant to reveal their private information about their valuation of performance when carriers can use the information not only to take more efficient precautions but also to exercise their market power more effectively. The revelation of this private information has a direct effect on efficiency by changing the level of carrier precaution. We have shown, however, that the

101. In the equilibrium in which the carrier offers a menu of contracts, even though information is revealed, the carrier commits to suboptimal reliance for the low-value shipper, and the outcome may involve lower overall welfare than if the information were not revealed. This type of outcome cannot occur in the context of misinformation about the rule of law. 
revelation of information can also affect efficiency by changing how people bargain.

This ancillary effect on efficiency can arise whenever one side of the contract has private information about the potential gains from trade and the other side has market power. The separation of market power and information between two contracting parties creates powerful incentives for strategic contractual behavior. An informed party who lacks market power will be reluctant to reveal the information if doing so will put it at a strategic disadvantage. This initial reluctance-whether or not it is ultimately overcome-induces strategic inefficiency. At times, the reluctance to reveal information will produce an inefficient form of obligational incompleteness because high-value carriers might fail to contract around a default that restricted their damages. ${ }^{102}$ This was one of Johnston's central insights. ${ }^{103}$

Nevertheless, even when the uninformed party discovers the relevant information by offering a menu of contracts, the contractual process of inducing separation is only accomplished by committing to inefficient contracts. Thus, the ancillary efficiency effects can cause not only inefficient pooling, but also inefficient separation. Our demonstration that inefficient menus can persist when there are zero transaction costs indicates that asymmetric information is not merely a source of strategic incompleteness; it can actually create inefficient contracts that fully specify all obligations.

We have focused on Hadley to exemplify strategic interactions and the possibility of contractual inefficiency in a concrete and well-known context. In that context, the asymmetric information concerning the shipper's value of performance is powerfully related to the carrier's ability to price discriminate. However, the contractual revelation of private information can have ancillary effects on efficiency in any contractual context in which one party has private information about the potential gains from trade and the other party has some market power.

Strategic inefficiencies, for example, can potentially be induced by several provisions of the Uniform Commercial Code. Section 2-210 allows any party to "perform his duty through a delegate unless otherwise agreed or unless the other party has a substantial interest in having his original promisor perform." 104 Under this section, as with Hadley, a promisee has a duty to put a promisor on notice that it has a substantial interest in the promisor's personal performance. Revealing this information, however, might put the promisee at a strategic disadvantage. Consider, for example, a promisee that has made

102. Previously, we have suggested that car dealers might fail to contract around a default rule that awarded them zero lost profits when buyers breach. Ayres \& Gertner, supra note 1, at 99 n.57; see also Johnston, supra note 1 , at 617 .

103. Johnston, supra note 1 , at 617.

104. U.C.C. $\S 2-210$ (1990). 
transaction-specific investments ${ }^{105}$ that only are valuable if used in conjunction with the promisor's personal performance. In this context, revealing the size of these investments might allow the promisor to expropriate part of the promisee's investment. ${ }^{106}$

Section 2-315 also forces promisees to put promisors on notice: "Where the seller at the time of contracting has reason to know any particular purpose for which the goods are required . . . there is unless excluded . . . an implied warranty that the goods shall be fit for such purpose."107 Yet revealing a special purpose for a project might also be correlated with—and hence might partially disclose - a buyer's willingness to pay. For instance, disclosing a particular use may have a direct effect on efficiency by allowing the seller to tailor the production process, but might also indicate that the buyer has an idiosyncratically high valuation. This ancillary effect of information disclosure again can distort the buyer's incentives to reveal information and can produce the same species of strategic inefficiency as in the foregoing model of consequential damages. ${ }^{108}$

The reluctance to contract for more efficient contractual obligations can stem from an incentive to conceal information about not only one's own willingness to pay, but also the other side's cost of performance. ${ }^{109}$ In a variety of contexts, promisees may be reluctant to raise issues that indicate that the promisor will have higher costs of performance. A wide variety of contracts in corporate finance, for example, routinely include arbitration clauses. Individual contractors may have idiosyncratic preferences for additional due process protection. They may be reluctant to suggest alternative provisions, however, because to do so might indicate that the individual is more litigious or more rigidly deontological, and thus more costly to deal with. This example also illustrates that strategic inefficiency does not only result from a reluctance to contract around a well-defined default. An aversion to making a counteroffer to a standard form contract can also exhibit a party's strategic reluctance to reveal private information. A strategic reluctance to reveal information may

105. See WILliamSON, supra note 2, at 62 (discussing transaction-specific investments).

106. See Benjamin Klein et al., Vertical Integration, Appropriable Rents, and the Competitive Contracting Process, 21 J.L. \& ECON. 297, $298-99$ (1978) (illustrating expropriation of quasi-rents with hypothetical example). The promisor could demand a higher price that the promisee would accept, because the value of this promisor's performance exceeds the value of alternative performance.

107. U.C.C. § 2-315 (1990).

108. The potential for strategic inefficiency based on asymmetric information can be found in virtually any obligational default rule. As a general matter, think of the scenario in which a party to the contract might have private information about a need to contract around the default, but has initial reluctance because of ancillary inferences that will be made by the other party. For a fairly prosaic example, consider U.C.C. $\S 2-308$ (1990), which establishes that "unless otherwise agreed . . . the place for delivery of goods is the seller's place of business ...." The buyer may have private information about the efficiency of having the seller deliver the goods elsewhere, but raising this might further the seller's ability to price discriminate.

109. The strategic inefficiencies in Hadley concern the former, because the uninformed carrier makes inferences about the shipper's value of performance, its willingness to pay. 
even have a "chilling" effect on how informed parties structure the provision in an initial offer. ${ }^{110}$

The examples in this Article of strategic contractual inefficiency continue the process of formally demonstrating that efficient contract law should be more than the set of hypothetical provisions for which most parties would contract. For the last decade, dozens of law and economics articles embarked on an almost unified search for the hypothetical or majoritarian defaults that would maximize efficiency in a variety of contractual settings. ${ }^{111}$ The new theories of strategic inefficiency provide stark counterexamples to the universal applicability of these standards. Yet in the wake of these new strategic theories, how broad is the attack? Some may argue that strategic inefficiencies, while theoretically possible, infect, at most, peripheral areas of contract.

The hypothetical contract analysis will produce efficient contractual rules in the broad variety of contexts where parties have symmetric information about all aspects of the transaction (including the legal rule). In these contexts, only the costs of contracting will induce obligational incompleteness, and majoritarian rules will ordinarily minimize the costs of contracting and failing to contract for efficient obligations. ${ }^{112}$

The settings in which strategic contractual behavior can undermine the use of majoritarian defaults, however, are not negligible. In a large number of contexts, the parties will have private (asymmetric) information about a variety of issues relevant to contractual efficiency. The strategic inefficiencies of double-sided, asymmetric information are all the more pathological in their complexity and have only begun to be analyzed. ${ }^{113}$

When the parties' knowledge is not symmetric, this Article has shown that choosing the efficient contract rule can entail an extraordinarily complex analysis-which depends on subtle pieces of information that lawmakers are unlikely to know. This practical indeterminacy of our model should not, however, be taken to undermine the appropriateness of either economic modeling or the goal of choosing efficient legal rules. Our model suggests that the task of pursuing any other normative theory of social welfare will be just as

110. In the corporate context, for example, it would not be surprising for the idiosyncratic buyer to offer an initial contract with an arbitration clause-even though without the ancillary effects she would prefer more procedural protection.

111. See Ayres \& Gertner, supra note 1, at 94; supra note 1 and accompanying text.

112. Even here, however, the majoritarian analysis needs to weigh the relative costs of contracting and failing to contract around particular defaults. As described in Ayres \& Gertner, supra note 1, at 103, the high costs that a minority of contractors might bear by failing to contract around a majoritarian rule might militate against the use of that default.

David Charny has argued, from a number of different justificatory perspectives (including the instrumental efficiency-based norm), for a limited use of the hypothetical standard. Charny, supra note 10, at $1877-88$.

113. See Johnston, supra note 1, at 634; see also Robert B. Myerson \& Mark A. Satterthwaite, Efficient Mechanisms for Bilateral Trading, 29 J. ECON. THEORY 265 (1983). 
complex, and therefore will encounter similar forms of indeterminacy. ${ }^{114}$ In our models, the same legal rule can produce dramatically different contracting behavior. Because it will be extremely difficult for lawmakers to predict what behavior will be produced by a given rule, it will be just as difficult for lawmakers to maximize equity as it is for them to maximize efficiency.

Moreover, the persistence of strategic inefficiencies-even when parties can costlessly contract for any rule-was shown to lead to the possibility that immutable restrictions on freedom to contract may at times be superior to less intrusive defaults. Asymmetric information often places contractors in a secondbest world of strategic interaction-one where small changes in the law can create large and, at times, perverse changes in contractual behavior. The practical institutional impossibility of choosing the best contractual structure may argue for the untailored rules of thumb suggested by Robert $S \operatorname{cott}^{115}$ and for the judicial "passivity" noticed by Alan Schwartz regarding interpretation of relational contracts. ${ }^{116} \mathrm{At}$ the very least, the new learning suggests that we should be more circumspect about our ability to divine efficient contract law when parties contract strategically.

114. For example, suppose policymakers desired to redistribute wealth from carriers to shippers. Policymakers would then want to encourage an equilibrium that maximizes shippers' gains from trade. As we have seen, however, determining the shippers' gains from trade and carrier's profits under asymmetric information involves the same difficulties involved in determining overall efficiency levels.

115. Scott, supra note 1; see also Eisenberg, supra note 21.

116. Alan Schwartz, Relational Contracts in the Courts: An Analysis of Incomplete Agreements and Judicial Strategies, 21 J. LEGAL STUD. (forthcoming June 1992). 


\section{APPENDIX}

In this appendix, we develop a simply analytic model of contracting under private information where the uninformed party has all the bargaining power. First, we analyze the profit-maximizing solution where there are zero transaction costs. We then extend the model to consider explicitly transactions costs and the effects of default rules on efficient contracting. We will continue the tradition of using the terminology of Hadley.

The basic setup is quite simple. There is a shipper who wishes to ship a crankshaft and a carrier with whom the shipper contracts for the transportation of the crankshaft. The value the shipper places on performance is private information. We assume that the shipper can be one of two types: either a highvalue shipper who values performance at $v_{h}$ or a low-value shipper who values performance at $v_{l}, v_{h}>v_{l}$. The carrier does not know whether the shipper is a high-or low-value one, but believes that the shipper is a high-value one with probability $\alpha$. We assume that it is prohibitively costly for the shipper to document her value to the carrier. After contracting, the carrier decides how much care to take. The likelihood of breach depends on the level of care, so that the probability of breach, denoted by $b$, is equal to $1-\sqrt{k}$ where $k$ is the monetary investment in precaution. ${ }^{17}$ The marginal cost of shipping beyond the precaution costs are zero. We assume all parties are risk-neutral.

We assume that the carrier's precaution decision cannot be contracted upon because of the prohibitive costs of verifying the reliance investment. ${ }^{118}$ Therefore, the carrier's reliance decision will be based upon the contracted liquidated damages clause. Given that a shipper signs a contract with liquidated damages $d$, the carrier will choose $k$ to minimize the sum of expected damages and precaution investment, $(1-\sqrt{k}) d+k$. The first-order condition is $-d l(2 \sqrt{k})+1=0$. Solving for $k$, gives

$$
k=\frac{d^{2}}{4}
$$

117. This exact functional form is unnecessary. The key features are that the function is convex in $k$ and that it is between 0 and 1 . In fact, this function can go below zero, so we assume that if $k>1, b=$ 0.

118. This assumption does not matter when there are no other contracting costs. If reliance investment is contractible, the carrier will still offer a menu of contracts to allow price discrimination. Since all parties are risk-neutral in our model, there is no insurance role for damages. All damages do is affect the level of precaution and thereby allow the carrier to screen on the basis of the differences in efficient precaution between types of shippers. Therefore, if it were costless to contract on reliance explicitly, the carrier would choose the level of reliance that is induced by the equilibrium level of damages chosen in our model. There is a one-to-one correspondence between damages and reliance, so contracting on one is equivalent to contracting on the other. Damages for violating the requirement must be set sufficiently high that the carrier would not want to cheat on reliance investment. However, when there are costs of contracting around a default damages rule, the inability to contract on reliance will affect equilibrium behavior. 
The probability of breach is

$$
b=1-\frac{d}{2}
$$

We first conisider take-it-or-leave-it offers from the carrier under the assumption that there are no transactions costs. The solution to the carrier's problem involves offering a menu of contracts - one designed for the high-value shipper and one designed for the low-value shipper. ${ }^{119}$ Each contract contains a price and liquidated damages clause.

The basic idea is to offer a contract for the high-value shipper that has a higher price than the one for the low-value shipper but that also has higher liquidated damages. Since the high-value shipper values performance more than the low-value shipper does, she is willing to accept the higher-priced contract because higher damages lead to greater precaution and a lower probability of breach. This benefits the high-value shipper more than it does the low-value shipper.

The problem for the carrier is to choose a pair of contracts to maximize expected profits subject to four constraints. There are two incentive-compatibility constraints: (1) the low-value shipper prefers the contract designed for her to the contract designed for the low-value shipper; and (2) the high-value shipper prefers the contract designed for her to the contract designed for the low-value shipper. There are two participation or individual-rationality constraints: each type prefers its contract to not contracting at all. We denote the contract designed for the high-value shipper by $\left(p_{h}, d_{h}\right)$ and the contract designed for the low-value shipper by $\left(p_{l}, d_{l}\right)$. In addition, we require that prices and damages are nonnegative.

The carrier's overall maximization problem is

$$
\max \alpha\left(p_{h}-b_{h} d_{h}-k_{h}\right)+(1-\alpha)\left(p_{l}-b_{l} d_{l}-k_{l}\right)
$$

subject to the following constraints:

$$
\begin{gathered}
\left(1-b_{h}\right) v_{h}+b_{h} d_{h}-p_{h} \geq\left(1-b_{l}\right) v_{h}+b_{l} d_{l}-p_{l} \\
\left(1-b_{l}\right) v_{l}+b d_{l}-p_{l} \geq\left(1-b_{h}\right) v_{l}+b_{h} d_{h}-p_{h} \\
\left(1-b_{h}\right) v_{h}+b_{h} d_{h}-p_{h} \geq 0
\end{gathered}
$$

119. It is conceivable that the carrier will not wish to separate the two types of shippers, in which case the menu can consist of two identical contracts. However, in our model this is never optimal. It is also possible that the carrier will choose to serve only the high-value shipper, in which case one can think of the second contract involving no trade. This does occur for some parameter values, and we analyze the possibility below. 


$$
\begin{gathered}
\left(1-b_{l}\right) v_{l}+b d_{l}-p_{l} \geq 0 \\
d_{h}, d_{l}, p_{h}, p_{l} \geq 0 .
\end{gathered}
$$

Of the four constraints ((4)-(7)), only the incentive-compatibility constraint for the high-value shipper and the participation constraint for the low-value shipper will be binding. Although the algebra needed to prove this is rather tedious, the intuition is quite simple. One of the participation constraints must be binding or else the carrier could both raise prices and increase profits. Indeed, it is the low-value shipper's participation constraint that must be binding since she values every contract less than the high-value shipper does. The high-value shipper's participation constraint must not be binding because if it were, the high-value shipper would get positive surplus from accepting the contract designed for the low-value shipper. Finally, the high-value shipper's incentivecompatibility constraint must be binding because it is the high-value shipper who wishes to pretend to be a low-value shipper in order to get a low price. If this constraint is binding, the low-value shipper's incentive constraint is satisfied so long as $d_{h}>d_{l}$. Therefore, all we need to do is substitute for $b_{h}$, $b_{l}, k_{h}, k_{l}, p_{h}, p_{l}$ from (1), (2), (4), and (7) to establish that a profit-maximizing carrier chooses $d_{h}, d_{l}$ maximize:

$$
\frac{\alpha}{4}\left[2 d_{h} v_{h}-d_{h}^{2}-2 d_{l}\left(v_{h}-v_{l}\right)\right]+\frac{(1-\alpha)}{4}\left(2 d_{l} v_{l}-d_{l}^{2}\right) .
$$

The first-order conditions imply

$$
d_{h}=v_{h}, d_{l}=\frac{\left(v_{l}-\alpha v_{h}\right)}{1-\alpha} .
$$

Substituting into the constraints,

$$
p_{h}=\frac{2 v_{h}(1-\alpha)-\left(v_{h}-v_{l}\right)\left(v_{l}-\alpha v_{h}\right)}{2(1-\alpha)}, p_{l}=\frac{\left(v_{l}-\alpha v_{h}\right)\left[2(1-\alpha)+\alpha\left(v_{h}-v_{l}\right)\right]}{2(1-\alpha)^{2}} \text {. }
$$

Finally, we can write expected profits and expected welfare (net gains from trade equaling sum of profits and shipper surplus) as:

$$
\Pi=\frac{\left(\alpha v_{h}^{2}-2 \alpha v_{h} v_{l}+v_{l}^{2}\right)}{4(1-\alpha)}, W=\frac{\left(\alpha v_{h}^{2}-2 \alpha^{2} v_{h}^{2}+2 \alpha^{2} v_{h} v_{l}+v_{l}^{2}-2 \alpha v_{l}^{2}\right)}{4(1-\alpha)} \text {. }
$$

If $v_{l}-\alpha v_{h}<0$ the solution involves a negative value for $d_{l}$, violating (8). In this case, the optimal strategy is to serve only the high-value shipper, charging a price of $v_{h}$ and liquidated damages of $v_{h}$. Expected profits are $\alpha v_{h}{ }^{2} / 4$. This is also the value of overall welfare because the carrier extracts all of the highvalue shipper's surplus.

We can compare the results to the full-information, first-best outcome. The full-information program is to choose $k_{b}, k_{h}$ to maximize 


$$
\alpha\left[\left(1-b_{h}\right) v_{h}-k_{h}\right]+(1-\alpha)\left[\left(1-b_{l}\right) v_{l}-k_{l}\right]
$$

The maximized value is

$$
W^{*}=\frac{1}{4}\left(\alpha v_{h}^{2}+v_{l}^{2}-\alpha v_{l}^{2}\right)
$$

Subtracting from (12), we get the welfare loss due to the second-best outcome of

$$
\frac{\left[\alpha\left(v_{h}-v_{)}\right)\right]^{2}}{4(1-\alpha)} .
$$

In the case in which the uninformed carrier only serves the high-value shipper, the difference in welfare is $(1-\alpha) v_{l}^{2} / 4$.

There are two types of inefficiency in this model. First, when the carrier offers a separating menu of contracts, the low-value shipper selects a contract with damages less than her valuation. This induces below-optimal reliance by the carrier. Second, the carrier may prefer just to serve the high-value shippers. This is a standard market-power, under-production inefficiency. If it is too difficult or costly to price discriminate and separate the two types of shippers, the carrier will not serve the low-value shippers.

In the absence of contracting costs, the damages default rule is irrelevant, since the carrier will clearly offer the same profit-maximizing contract or menu of contracts independent of the default rule. However, if we introduce direct costs of writing complicated contracts, default rules have a role. Therefore, we now introduce these costs. We assume that it costs the carrier nothing to offer a contract that is a single price. However, if she offers a contract with a liquidated damage clause, she incurs a cost $c_{d}$. If the carrier offers a menu of contracts, she incurs a cost $c_{m}$. Therefore, if the carrier offers a menu of contracts each with liquidated damages, she pays $c_{d}+c_{m}$; if she offers a single contract designed for the high-value shipper with a liquidated damages clause, she pays $c_{d}$; and if she offers a single price contract with default damages, he pays no transaction costs.

We analyze two different default rules. Under a consequential damages default, the carrier pays damages equal to the shipper's valuation if there is a breach. We assume that it is costless for the court to determine the valuations ex post, even thought it is prohibitively expensive prior to breach. Under a foreseeable damages default, the carrier pays damages equal to the foreseeable loss from the breach. We make this rule operational by setting damages equal to the low-value types' valuation.

First, we consider consequential damages. If the carrier serves both types with a single price under the default rule, she incurs no transactions costs. 
However, precaution expenditures will be the same for both types of shipper, since shippers do not separate themselves. Denoting the expected valuation of the shipper $\alpha v_{h}+(1-\alpha) v_{l}$, by $\bar{v}$ we get that $k=\bar{v}^{2} / 4$ and $b=1-\bar{v} / 2$. The carrier sets price such that the low-value shipper gets no surplus, so $p=$ $v_{l}$. Expected profits are

$$
v_{l}-\frac{\bar{v}^{2}}{4}-\left(1-\frac{\bar{v}}{2}\right) \bar{v}=\frac{\bar{v}^{2}}{4}-\alpha\left(v_{h}-v_{l}\right)
$$

The high-value shipper pays $v_{l}$ but gets benefits $v_{h}$ independent of breach, so her surplus is $v_{h}-v_{l}$. Overall welfare is therefore $\vec{v} / 4$.

Under consequential damages, it is also possible that the carrier will only serve the high-value shipper. The efficient level of damages is $v_{h}$, which is equal to the default consequential damages, so the carrier will not incur any transaction costs. As in the zero transaction costs case, profits and welfare are both $\alpha v_{h}^{2} / 4$.

Of course, the carrier may incur transactions costs by offering a contract or a menu of contracts with liquidated damages clauses. If he offers a menu of contracts, it is clearly optimal to offer the menu derived above in the no transaction costs case. The only difference is that profits and welfare are reduced by $c_{d}+c_{m}$.

Alternatively, the carrier can offer a single contract with a liquidated damages clause that both types of shippers accept. It is simple to show that the optimal liquidated damages is $v_{l}$, so $p=v_{l}$. This result may seem somewhat nonintuitive because the welfare-maximizing level of damages is $\bar{v}$ not $v_{l}$. When the carrier serves both types with the same liquidated damages contract, however, it is constrained to charge both types a price that gives the low-value shipper nonnegative surplus. Expected profits are maximized by choosing the damages rule that maximizes the low-value shipper's welfare. Expected profits equal $v_{l}^{2} / 4-c_{d}$, the high-value shipper gets surplus of $1 / 2 v_{l}\left(v_{h}-v_{l}\right)$, and expected welfare is $1 / 4\left[(I-2 \alpha) v_{l}^{2}+2 \alpha v_{l} v_{h}\right]-c_{d^{*}}$.

Now let us consider a foreseeable damages default rule. If the carrier serves both types under the default rule, $k=v_{l}^{2} / 4$ and $b=1-v_{l} / 2$. The carrier sets a price so that the low-value shipper gets no surplus, $p=v_{l}$. Expected profits are $v_{l}^{2} / 4$, the high-value shipper gets a surplus of $1 / 2 v_{l}\left(v_{h}-v_{l}\right)$, and expected welfare is $\left[(1-2 \alpha) v_{l}^{2}+2 \alpha v_{l} v_{h}\right] / 4$.

Instead, the carrier could sell only to the high-value shipper under the default rule. Since damages are still $v_{b}$, precaution investment is the same as in the previous case, but price is set to give the high-value shipper no surplus. This price is $v_{l}+1 / 2 v_{l}\left(v_{h}-v_{l}\right)$. Expected profits and welfare are $1 / 4 v_{l}\left(2 v_{h}-v_{l}\right)$.

Alternatively, the carrier can write around the default rule. She can incur transactions costs $c_{d}+c_{m}$ by offering the separating menu of contracts. She can offer a single-price contract, serving both types with a consequential damages 
clause, which we solved for above incurring transactions $\operatorname{costs} c_{d}$ in the process. A final alternative is to serve only the high-value shipper with damages set to $v_{h}$, incurring transactions costs $c_{d}$. The outcome under this alternative is also solved for above.

The formulas for profits, welfare, and transaction costs for all the possible scenarios are summarized in Table 1: the first column gives the shippers served and contractual damages; the second and third columns give expected profits and expected welfare given zero transaction costs; and the final two columns give the transaction costs that must be incurred if the carrier wishes to reach the given outcome.

Comparisons of welfare, given that both types of firms are served and transaction costs are zero, indicate that if it is sufficiently likely that the shipper is high-value, welfare is higher under either foreseeable or consequential damages than under the separation menu. Welfare under a consequential damages clause is always higher than under a foreseeable damages cause. Welfare is always higher when serving both types than when serving only the high type. Again, absent transaction costs, profits are always higher under the separating menu than they are when serving both types under either foreseeable or consequential damages. Profits can be higher serving only high-value shippers than they are serving both.

The differences between profits and welfare drive the complicated results demonstrated in the graphs. The equilibrium is second best when the carrier has market power even in the absence of transactions costs, since he chooses the regime that maximizes profits, not welfare. Given the second-best nature of the zero transactions cost equilibrium, it should not be surprising that the introduction of transactions costs has complex and ambiguous effects on contract choice, welfare, and optimal default choice. 


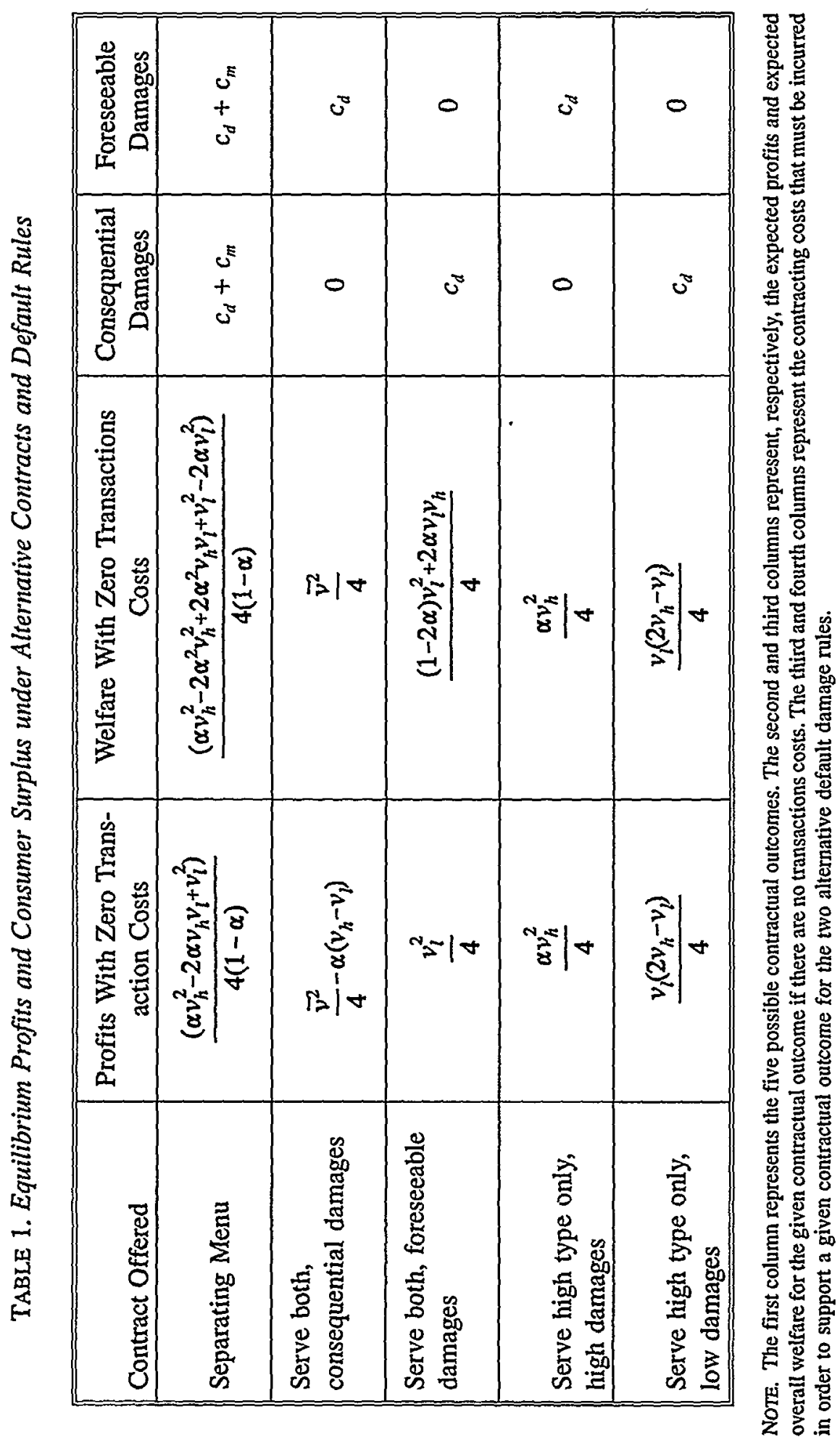


HeinOnline -- 101 Yale L.J. 774 1991-1992 